\title{
INL High Performance Building Strategy
}

\author{
Christopher P. Ischay \\ Ernest L. Fossum \\ July 2013
}

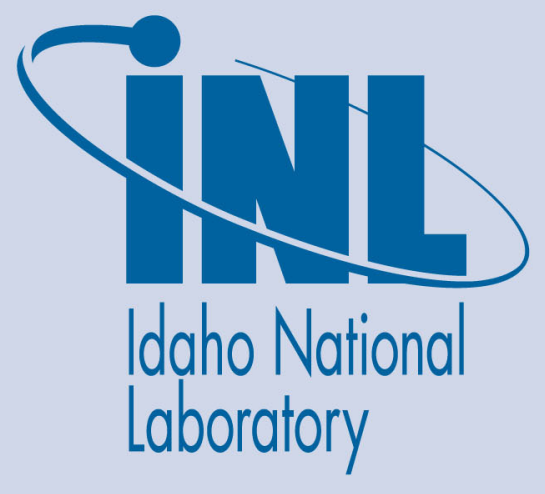

The INL is a U.S. Department of Energy National Laboratory operated by Battelle Energy Alliance 


\section{DISCLAIMER}

This information was prepared as an account of work sponsored by an agency of the U.S. Government. Neither the U.S. Government nor any agency thereof, nor any of their employees, makes any warranty, expressed or implied, or assumes any legal liability or responsibility for the accuracy, completeness, or usefulness, of any information, apparatus, product, or process disclosed, or represents that its use would not infringe privately owned rights. References herein to any specific commercial product, process, or service by trade name, trade mark, manufacturer, or otherwise, does not necessarily constitute or imply its endorsement, recommendation, or favoring by the U.S. Government or any agency thereof. The views and opinions of authors expressed herein do not necessarily state or reflect those of the U.S. Government or any agency thereof. 
INL/EXT-10-17808

Revision 1

\title{
INL High Performance Building Strategy
}

\author{
Christopher P. Ischay
}

Ernest L. Fossum

July 2013

Idaho National Laboratory Idaho Falls, Idaho 83415

http://www.inl.gov

\author{
Prepared for the \\ U.S. Department of Energy \\ Office of Nuclear Energy \\ Under DOE Idaho Operations Office \\ Contract DE-AC07-05ID14517
}





\title{
INL High Performance Building Strategy
}

\author{
INL/EXT-10-17808 \\ Revision 1
}

July 2013

Approved by:
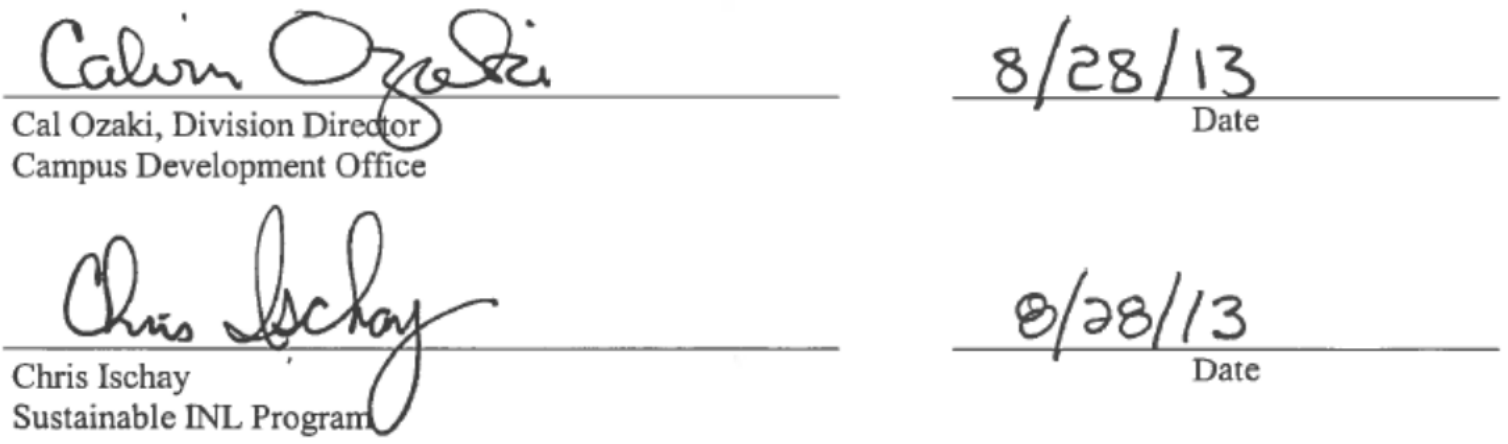



\section{EXECUTIVE SUMMARY}

High performance buildings, also known as sustainable buildings and green buildings, are resource efficient structures that minimize the impact on the environment by using less energy and water, reduce solid waste and pollutants, and limit the depletion of natural resources while also providing a thermally and visually comfortable working environment that increases productivity for building occupants.

As Idaho National Laboratory (INL) becomes the nation's premier nuclear energy research laboratory, the physical infrastructure will be established to help accomplish this mission. This infrastructure, particularly the buildings, should incorporate high performance sustainable design features to be environmentally responsible and reflect an image of progressiveness and innovation to the public and prospective employees.

Additionally, INL is a large consumer of energy that contributes to both carbon emissions and resource inefficiency. In the current climate of rising energy prices and political pressure for carbon reduction, this guide will help construction project teams design facilities that are sustainable and reduce energy costs, thereby reducing carbon emissions.

With these concerns in mind, the recommendations described in the INL High Performance Building Strategy are intended to form the INL foundation for high performance building standards. This revised strategy incorporates the latest Federal and DOE orders and directives including Executive Order (EO) 13514, "Federal Leadership in Environmental, Energy, and Economic Performance," EO 13423, "Strengthening Federal Environmental, Energy, and Transportation Management," DOE Order 436.1, "Departmental Sustainability," the DOE Strategic Sustainability Performance Plan (SSPP), the "INL Site Sustainability Plan" (SSP), the latest guidelines, trends, and observations in high performance building construction, and the latest changes to the "Leadership in Energy and Environmental Design $\left(\right.$ LEED $\left.^{\circledR}\right)$ Green Building Rating System” (LEED 2009).

This document employs a two-path approach for high performance sustainable buildings at INL. The first path identifies the requirements of the Guiding Principles for Federal Leadership in High Performance and Sustainable Buildings, and the second path discusses the requirements of LEED Gold certification. 


\section{CONTENTS}

EXECUTIVE SUMMARY vii

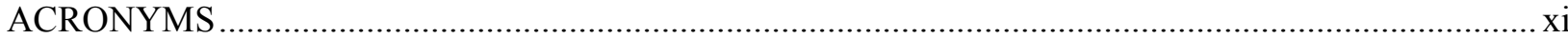

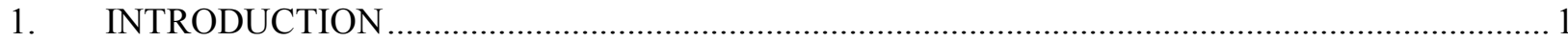

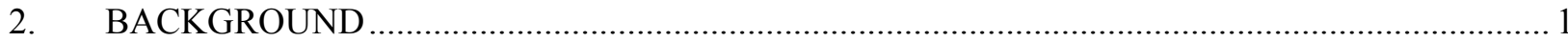

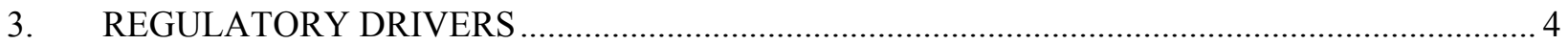

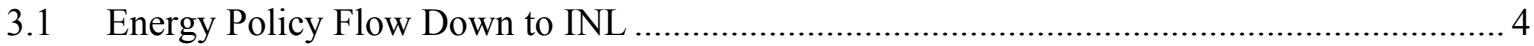

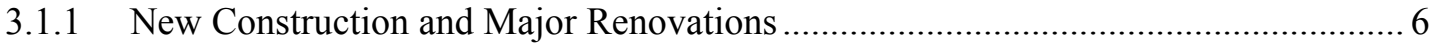

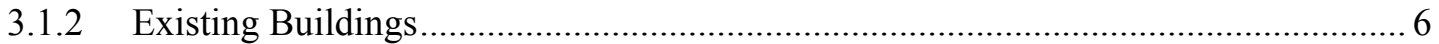

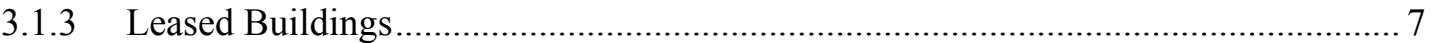

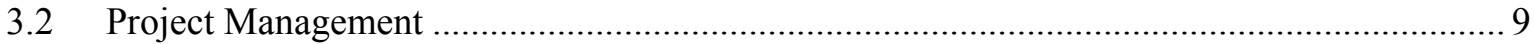

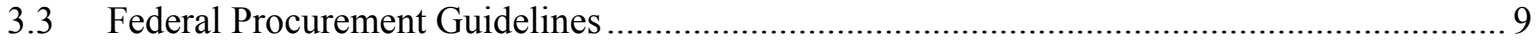

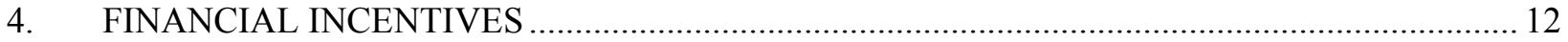

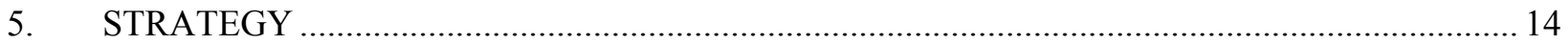

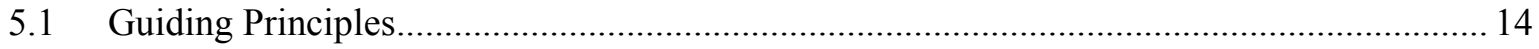

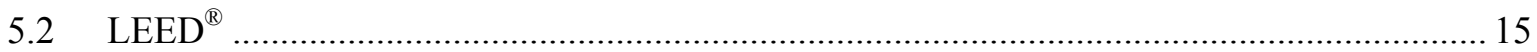

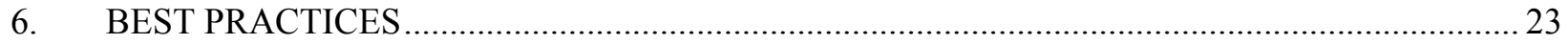

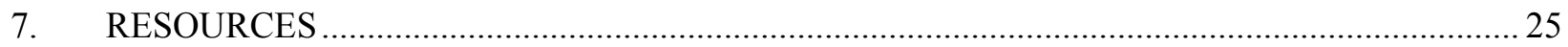

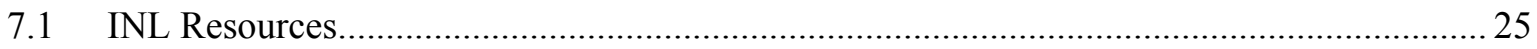

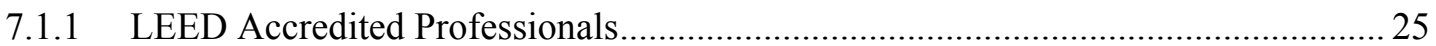

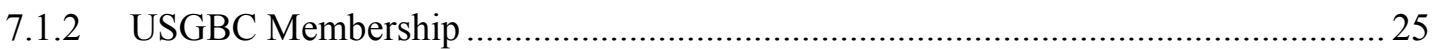

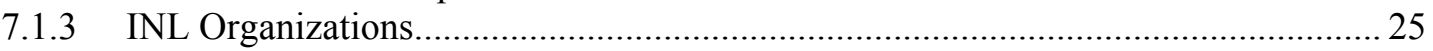

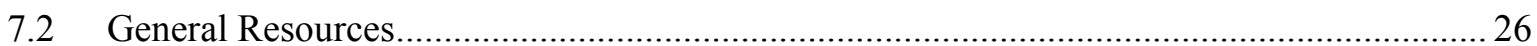

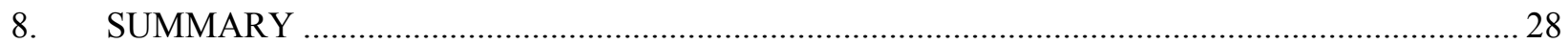

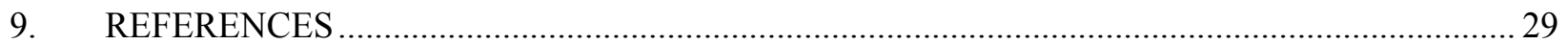

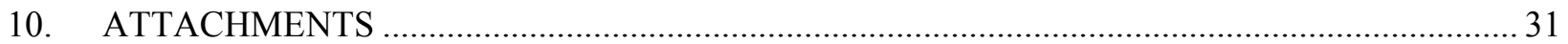

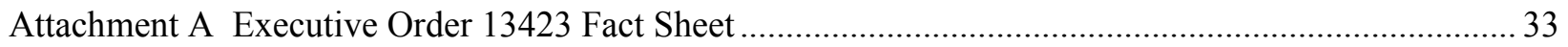

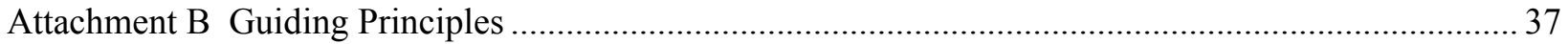




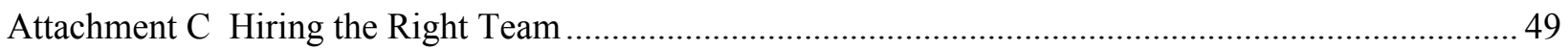

Attachment D Integrated Design Steps for Designers .................................................................... 55

Attachment E Checklist for $\operatorname{LEED}^{\circledR}$ for New Construction.................................................................. 59

Attachment F Checklist for LEED ${ }^{\circledR}$ for Existing Buildings: Operations \& Maintenance ......................... 63

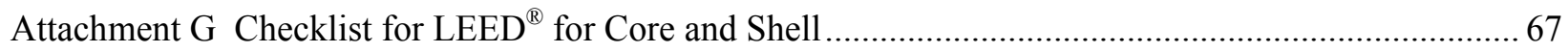

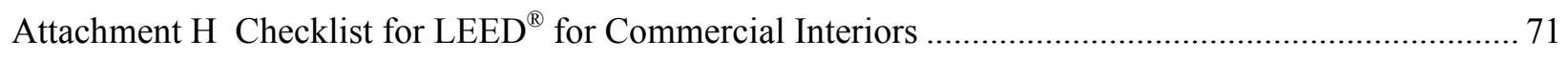

\section{FIGURE}

Figure 1. Cost comparison of non- LEED laboratory buildings to LEED laboratory buildings (Matthiessen and Morris 2007).

TABLES

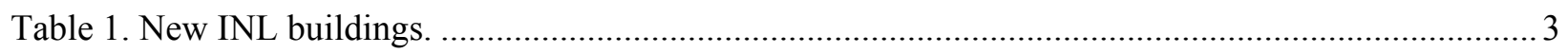

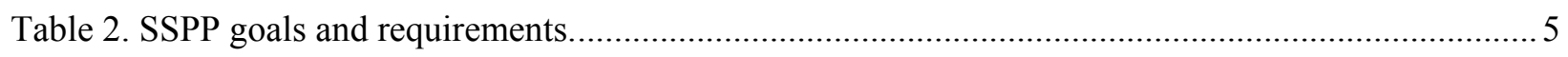

Table 3. Key for Recommended LEED NC Checklist to use as a Guide at INL................................... 16

Table 4. Recommended LEED NC Checklist to use as a Guide at INL................................................ 17 


\section{ACRONYMS}

AP

Accredited Professional

ASHRAE American Society of Heating, Refrigeration, and Air Conditioning Engineers

ATR

Advanced Test Reactor

BEA

Battelle Energy Alliance, LLC

BIM

Building Information Modeling

C\&D

Construction and Demolition

CAES

Center for Advanced Energy Studies

CI

Commercial Interiors

CIEB Continual Improvement of Existing Building

CS

Core and Shell

DOE

Department of Energy

EB

Existing Buildings

EIA

Energy Information Administration

EISA

Energy Independence and Security Act

EO

Executive Order

EPA

Environmental Protection Agency

EPAct Energy Policy Act

FAQ Frequently Asked Question

FAR Federal Acquisition Regulation

FY Fiscal Year

GBCI Green Building Certification Institute

GSA General Services Administration

HVAC heating, ventilation, and air conditioning

IDL Integrated Design Lab

ILA Industrial, Landscaping, and Agricultural

IMCL Irradiated Materials Characterization Lab

INL Idaho National Laboratory

ISWG Interagency Sustainability Working Group

LEED $^{\circledR} \quad$ Leadership in Energy and Environmental Design

$\mathrm{M} \& \mathrm{~V} \quad$ Measurement and Verification

MFC Materials and Fuels Complex

NC New Construction

NECPA National Energy Conservation Policy Act

O\&M operations and maintenance

OFEE Office of the Federal Environmental Executive

OMB Office of Management and Budget 
PEMP Performance Evaluation and Measurement Plan

PUE Power Utilization Effectiveness

REC Research and Education Campus

REL Research and Education Laboratory

RESL Radiological and Environmental Science Laboratory

SOW Statement of Work

SPO Sustainability Performance Office

SSP Site Sustainability Plan

SSPP Strategic Sustainability Performance Plan

T\&FR Technical and Functional Requirements

USGBC U.S. Green Building Council

VOC Volatile Organic Compound 


\section{INL High Performance Building Strategy}

\section{INTRODUCTION}

The Department of Energy's (DOE) vision for Idaho National Laboratory (INL) is that it will enhance the nation's energy security by becoming the preeminent, world-class, nuclear research development and demonstration laboratory. To achieve this goal, additional state-of-the-art facilities are required at INL.

INL is composed of four modern campuses that are necessary to achieve the DOE objectives: the Research and Education Campus (REC), Advanced Test Reactor (ATR) Complex, Materials and Fuels Complex (MFC), and the Specific Manufacturing Complex (SMC). As it moves forward in the design and construction of new facilities, INL will demonstrate its sustainability commitment by incorporating high performance building elements in the design specifications.

Construction of new facilities can be achieved through various funding mechanisms including private-sector funding, university funding, and government line-item funding; therefore, it is important to clarify INL's high performance building goals and commitment to sustainability in advance.

The goal of this document is to establish the foundation at INL for the design and construction of high performance sustainable buildings. The focus is on the technical and functional requirements (T\&FR) that address the environmental issues specific to this geographical region as well as those that are good economical sustainable practices such as energy efficiency and materials minimization. Overall, INL can improve the way its buildings are designed, constructed, and leased by committing to sustainability goals while also meeting applicable executive and DOE orders.

Revision 1 of this document incorporates the latest federal and DOE orders that have been introduced since the original version was released in 2005, including Executive Order (EO) 13514, "Federal Leadership in Environmental, Energy, and Economic Performance" (2009), EO 13423, "Strengthening Federal Environmental, Energy, and Transportation Management" (2007), DOE O 436.1, "Departmental Sustainability" (2011), the "DOE Strategic Sustainability Performance Plan" (SSPP), the "INL Site Sustainability Plan" (SSP), the latest guidelines, trends, and observations in high performance building construction, and the latest changes to the Leadership in Energy and Environmental Design (LEED ${ }^{\circledR}$ ) Green Building Rating System (LEED $\left.{ }^{\circledR} 2009\right)$.

This revised High Performance Building Strategy has been aligned with the DOE Strategic Sustainability Performance Plan (SSPP) and employs a two-path approach: the "Guiding Principles for Federal Leadership in High Performance and Sustainable Buildings set forth in the Federal Leadership in High Performance and Sustainable Buildings Memorandum of Understanding" (WBDG 2006) (referred to from here on as the "Guiding Principles" ), and LEED Gold certification. The first path identifies the requirements of the Guiding Principles, and the second path discusses the requirements of LEED Gold certification. The Guiding Principles are divided into two sections, one for new construction and major renovations, and the other for existing buildings. Compliance with the Guiding Principles is a federal requirement and is not optional. LEED certification can be used to show equivalency with the Guiding Principles.

\section{BACKGROUND}

In the U.S., commercial and residential buildings consume almost $40 \%$ of the energy and $72 \%$ of all electricity (Environmental Information Administration 2008), while accounting for $38 \%$ of all $\mathrm{CO}_{2}$ emissions (Energy Information Administration 2008). Buildings are also large consumers of natural

a. The latest version of the Guiding Principles is a revision from the January 2006 version from the Federal Leadership in High Performance and Sustainable Buildings Memorandum of Understanding that was signed by federal agencies, including DOE. The 2008 revision was issued by the Interagency Sustainability Working Group, a subcommittee of the Steering Committee established by EO 13423. 
resources as they use $40 \%$ of the raw materials globally and $13.6 \%$ of all potable water nationally. The goal of green or high performance building design is to use a holistic approach to lessen a building's impact on the environment.

High performance buildings offer a number of benefits including:

- Reduce water and energy consumption

- Minimize consumption of virgin materials

- Reduce waste going to landfills

- Lessen the embodied energy of the building materials

- Provide a well-ventilated, comfortable environment that promotes occupant productivity

- Use interior materials that do not off-gas harmful pollutants, such as Volatile Organic Compounds (VOCs)

- Provide a healthy environment for their occupants and thus reduce sick building syndrome and absenteeism, while increasing employee retention.

As INL works to advance nuclear energy as an alternative to fossil fuel consumption, it is important to showcase INL's progressive, innovative, and environmentally responsible character. This is particularly effective by designing and constructing new high performance LEED-certified buildings.

The LEED Rating System and certification by the U.S. Green Building Council (USGBC) is the industry standard peer-reviewed mechanism for validating the design and construction of green buildings. While there is a small initial investment for preparing the LEED submittal package and the administrative fees to the USGBC for registering and certifying a building, the cost premium is easily recovered in the reduced energy and operating costs of the building over its life. Furthermore, the documentation deliverables and building commissioning process required by LEED help to ensure that the building will perform according to its design potential.

DOE has adopted the LEED Rating System, and multiple other federal agencies have adopted LEED Silver or Gold as a minimum performance standard for new buildings, with a preference for LEED Platinum. Within the DOE complex, an increasing number of sites have achieved or are in the process of receiving LEED certification on new buildings. For a full list of all federal and private buildings certified through the USGBC, see www.usgbc.org/LEED/Project/CertifiedProjectList.aspx.

INL has several building that achieved LEED certification including:

- Center for Advanced Energy Studies (LEED Gold)

- ATR-Complex Test Train Assembly Building (LEED Certified - Pending)

- ATR-Complex Common Support Building (LEED Certified)

- Radiological Environmental Sciences Laboratory (LEED Gold)

- Energy Systems Laboratory (LEED Gold)

- MFC Irradiated Materials Characterization Laboratory (LEED Gold)

- Research and Education Laboratory (LEED Gold - Pending). 
Additional information on these facilities is shown in Table 1.

Table 1. New INL buildings.

\begin{tabular}{|c|c|c|c|c|c|}
\hline Category & Name & Area & $\begin{array}{l}\text { Square } \\
\text { Footage }\end{array}$ & Status & $\begin{array}{c}\text { Design and } \\
\text { Performance Goal }\end{array}$ \\
\hline \multirow{2}{*}{$\begin{array}{l}\text { New Facilities } \\
\text { Major } \\
\text { Renovations } \\
<\$ 5 \mathrm{M} \text { Capital }\end{array}$} & Test Train Assembly Facility & ATR & 4,483 & Complete & LEED Certified \\
\hline & $\begin{array}{l}\text { ATR Complex Technical } \\
\text { Support Building }\end{array}$ & ATR & 16,592 & Complete & LEED Certified \\
\hline \multirow{2}{*}{$\begin{array}{l}\text { New Facilities } \\
\text { Major } \\
\text { Renovations } \\
>\$ 5 \mathrm{M} \text { Capital }\end{array}$} & $\begin{array}{l}\text { Irradiated Materials } \\
\text { Characterization Lab (IMCL) }\end{array}$ & MFC & 12,147 & Complete & LEED Gold \\
\hline & $\begin{array}{l}\text { Radiological and } \\
\text { Environmental Science } \\
\text { Laboratory (RESL) }\end{array}$ & REC & 13,583 & Complete & LEED Gold \\
\hline \multirow{2}{*}{ Leases } & $\begin{array}{l}\text { INL Energy Systems } \\
\text { Laboratory (ESL) }\end{array}$ & REC & 90,283 & Complete & LEED Gold \\
\hline & $\begin{array}{l}\text { Research and Education } \\
\text { Laboratory (REL) }\end{array}$ & REC & 132,523 & Construction & LEED Gold \\
\hline
\end{tabular}

INL's vision is to be a leading laboratory for sustainability performance in the United States and globally. Achieving sustainability means simultaneous consideration of economic prosperity, environmental quality, and social equity.

The sustainability strategy supports the long-term objective to ensure the efficient and appropriate use of laboratory lands, energy, water, and materials, as well as the services that rely on them. INL will move beyond compliance-oriented initiatives to sustainability as the key strategy for achieving both a competitive advantage and meaningful change. This transformation sharpens INL's focus on new designs, building upgrades, and scientific research.

The Sustainable INL Program was established in September 2007 and is part of a movement among federal agencies to evaluate current processes and establish goals for achieving sustainability. Its intent is to continue innovation and research while simultaneously improving energy efficiency, becoming responsible environmental stewards, and conserving natural resources. Focus areas within the program include those covered in the DOE SSPP. The Sustainable INL Program relies on management and employee participation to achieve its goals. Visit www.inl.gov/sustainable, or contact Chris Ischay (Program Manager, 208-526-4382, christopher.ischay@inl.gov) or Ernest Fossum (Energy Manager, 208-526-2513, ernest.fossum@inl.gov) with any questions. 


\section{REGULATORY DRIVERS}

In addition to the sustainable benefits previously discussed, an additional reason for occupying and selecting buildings with high performance sustainable features is due to the regulatory requirements of Executive and DOE orders, which are discussed below. The requestor and project manager for a new, leased, or existing INL building project is responsible for ensuring that all applicable Executive and DOE orders are met, which include EO 13423, "Strengthening Federal Environmental, Energy, and Transportation Management," EO 13514, "Federal Leadership in Environmental, Energy, and Economic Performance," the National Energy Conservation Policy Act (NECPA), the Energy Policy Acts (EPAct) of 1992 and 2005, the Energy Independence and Security Act (EISA) of 2007, and the Pollution Prevention Act of 1990.

\subsection{Energy Policy Flow Down to INL}

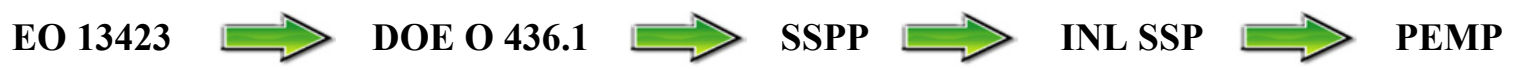

EO 13423 sets goals for federal agencies in the areas of energy efficiency, renewable energy, reduction of toxic substances, recycling, sustainable buildings, electronics stewardship, fleet efficiency, and water conservation. The EO 13423 Fact Sheet has been included in Attachment A for more information.

The EO 13423, Sec. 2(f), sustainable building goals are to:

"ensure that (i) new construction and major renovations of agency buildings comply with the Guiding Principles for Federal Leadership in High Performance and Sustainable Buildings set forth in the Federal Leadership in High Performance and Sustainable Buildings Memorandum of Understanding (2006), and (ii) 15 percent of the existing Federal capital asset building inventory of the agency as of the end of fiscal year 2015 incorporates the sustainable practices in the Guiding Principles."

EO 13423 was given further strength when it was codified as law as part of the Omnibus bill signed in spring 2009.

The instructions for implementing EO 13423 contain specific details for implementation of the goals mentioned above:

"(1) New construction and renovation. Beginning with the FY 2007 funding cycle, when planning the funding and design for construction of buildings that meet the agency-defined capital asset threshold, each agency shall meet or exceed statutory goals and address each of the five Guiding Principles for Federal Leadership in High Performance and Sustainable Buildings (Guiding Principles). Written justification must be provided to OFEE and OMB if an agency proposes not to comply. In order to apply the Guiding Principles to building projects, all business cases for new building construction or major renovations, developed per OMB A-11, Part 7, Section 300, shall incorporate the Guiding Principles to the greatest extent practicable. These requirements apply to construction of new Federal buildings; new, renegotiation, or extension of leases for Federal occupancy, or major renovation projects. (2) Existing buildings. In addition, by the end of 2015, agencies shall meet the 15 percent goal in E.O. 13423 section 2(f)(ii) for incorporating the sustainable practices in the Guiding Principles into their Federal capital asset building inventory. The 15 percent goal for existing buildings applies to an agency's full building inventory as it exists in FY 2015, including any new buildings brought on line and excluding any unneeded buildings disposed of or sold prior to 2015. Therefore, agencies should strongly consider incorporating sustainable practices into projects underway and selling or disposing of unneeded assets. " 
DOE Order 436.1 is the document that connects the federal orders and directives to DOE and outlines the path for implementation. Section 4, "Requirements," directs DOE to "Comply with the sustainability requirements contained in EO 13423, EO 13514, the NECPA, EPAct 1992 and 2005, EISA of 2007, and continue to adhere to the inventory and reporting requirements of Section 301 through 313 (including implementing regulations) of the Emergency Planning and Community Right-to-Know Act, the Pollution Prevention Act of 1990 at DOE facilities, and related statutory and administrative requirements." DOE Order 436.1 is a very brief order that basically flows down the EOs and federal directives to DOE. DOE Order 436.1 also requires that DOE prepares an annual SSPP. INL implements the SSPP through the INL SSP and performance measures in the INL Performance Evaluation and Measurement Plan (PEMP).

The SSPP goals and requirements applicable to the design, construction, and operation of High Performance Sustainable Buildings are summarized in Table 2.

Table 2. SSPP goals and requirements.

\begin{tabular}{|c|c|}
\hline Goal Area & Goal or Requirement Description \\
\hline $\begin{array}{l}\text { Green House } \\
\text { Gases }\end{array}$ & $\begin{array}{l}\text { Reduce Scopes } 1 \text { and } 2 \text { GHG emissions by } 28 \% \text { by Fiscal Year (FY) } 2020 \text { from } \\
\text { an FY } 2008 \text { baseline. } \\
\text { Reduce Scope } 3 \text { GHG emissions by } 13 \% \text { by FY } 2020 \text { from an FY } 2008 \text { baseline. }\end{array}$ \\
\hline Energy Efficiency & 30\% energy intensity $\left(\mathrm{Btu} / \mathrm{ft}^{2}\right)$ reduction by FY 2015 from an FY 2003 baseline. \\
\hline Metering & $\begin{array}{l}\text { Individual buildings metered for } 90 \% \text { of electricity, steam, natural gas, and } \\
\text { chilled water by FY } 2015 \text {. }\end{array}$ \\
\hline Cool Roofs & $\begin{array}{l}\text { All new roofs must be a Cool Roof and must have a minimum thermal resistance } \\
\text { of R-30. }\end{array}$ \\
\hline Guiding Principles & $\begin{array}{l}15 \% \text { of existing buildings greater than } 5,000 \mathrm{ft}^{2} \text { must be compliant with the } \\
\text { Guiding Principles for Sustainable Existing Buildings by FY } 2015 \text {. }\end{array}$ \\
\hline New Construction & $\begin{array}{l}\text { All new construction, major renovations, and alterations of buildings greater than } \\
5,000 \mathrm{ft}^{2} \text { must comply with the Guiding Principles for Sustainable New } \\
\text { Construction and Major Renovations. }\end{array}$ \\
\hline Renewable Energy & $\begin{array}{l}7.5 \% \text { of annual electricity consumption from renewable sources by FY } 2013 \text { and } \\
\text { thereafter. }\end{array}$ \\
\hline Water Efficiency & $\begin{array}{l}26 \% \text { water intensity }\left(\mathrm{gal} / \mathrm{ft}^{2}\right) \text { reduction by FY } 2020 \text { from an FY } 2007 \text { baseline. } \\
20 \% \text { water consumption reduction of industrial, landscaping, and agricultural } \\
\text { (ILA) water by FY } 2020 \text { from an FY } 2010 \text { baseline. }\end{array}$ \\
\hline Waste Diversion & $\begin{array}{l}\text { Divert at least } 50 \% \text { of non-hazardous solid waste by FY } 2015 \text {. } \\
\text { Divert at least } 50 \% \text { of Construction and Demolition (C\&D) materials and debris } \\
\text { by FY } 2015 \text {. }\end{array}$ \\
\hline Procurement & $\begin{array}{l}\text { Procurements meet sustainability requirements and include sustainable acquisition } \\
\text { clause }(95 \% \text { each year). }\end{array}$ \\
\hline Data Centers & $\begin{array}{l}\text { All data centers are metered to measure a monthly Power Utilization } \\
\text { Effectiveness (PUE) } 100 \% \text { by FY } 2015 \text {. } \\
\text { Maximum annual weighted average PUE of } 1.4 \text { by FY } 2015 \text {. }\end{array}$ \\
\hline $\begin{array}{l}\text { Electronics } \\
\text { Stewardship }\end{array}$ & $\begin{array}{l}100 \% \text { of eligible PCs, laptops, and monitors with power management activity } \\
\text { implemented and in use by FY } 2012 .\end{array}$ \\
\hline
\end{tabular}




\subsubsection{New Construction and Major Renovations}

All new construction and major renovation projects for buildings greater than 5,000 $\mathrm{ft}^{2}$ are to follow the Guiding Principles as established by EO 13423. EO 13423, Sec 2(f)(i), states "New construction and major renovations of agency buildings comply with the Guiding Principles for Federal Leadership in High Performance and Sustainable Buildings set forth in the Federal Leadership in High Performance and Sustainable Buildings Memorandum of Understanding (2006)." "The Guiding Principles for Sustainable New Construction and Major Renovations," establish the performance standards for New Construction and Major Renovation projects.

For new construction and major renovations, there are two options for compliance with the Guiding Principles:

1. OPTION NC-1

An agency can demonstrate that a building is compliant with each of the five Guiding Principles for Sustainable New Construction and Major Renovations (provided in Attachment B, "Guiding Principles").

2. OPTION NC-2

The building is third-party certified to meet the requirements of a multi-attribute green building standard or rating system developed by an ANSI-accredited organization.

Note that the preferred INL method for New Construction and Major Renovation projects is achieving a minimum of LEED NC-Gold certification. Buildings certifying as LEED NC-Gold are considered to be equivalent and to comply with the Guiding Principles. The specifics of LEED are discussed further in Section 5.2.

For planning and information purposes, EO 13514 requires that, beginning in FY 2020, all new building starts must be net zero facilities. This requirement means that the building must generate as much energy as it uses. The best strategy for constructing a net-zero building is to design to the lowest energy use practical and then install renewable generation to provide that energy load. Funding and designing such buildings will be a challenge, but designing to LEED Gold certification standards and implementing the Guiding Principles will assist in preparing INL for this new requirement.

\subsubsection{Existing Buildings}

EO 13514 Sec 1 (g) (iii) addresses existing buildings as follows:

"Ensuring that at least 15 percent of agency's existing buildings (above 5,000 $\mathrm{ft}^{2}$ ) and building leases (above 5,000 $\mathrm{ft}^{2}$ ) meet the Guiding Principles by fiscal year 2015 and that the agency makes annual progress toward 100\% conformance with the Guiding Principles for its building inventory."

For existing buildings, there are two options for compliance with the Guiding Principles:

1. OPTION EB-1

An agency can demonstrate that a building is compliant with each of the five Guiding Principles for Sustainable Existing Buildings (provided in Attachment B)

\section{OPTION EB-2}

The building was third-party certified to meet the requirements of a multi-attribute green building standard or rating system developed by an ANSI-accredited organization.

NOTE that the preferred INL method for Existing Facilities is documenting the Guiding Principles including compiling data and achieving an Energy Star rating of 75 or higher. 
The Guiding Principles for Sustainable Existing Buildings cover sustainable operational and performance aspects of existing buildings. Full implementation of the Guiding Principles for Sustainable Existing Buildings may require upgrade projects to improve performance or enhance operations. Documentation of the Guiding Principles for Sustainable Existing Buildings is typically accomplished by using the Federal High Performance Sustainable Building Checklist that is contained in the EPA Energy Star Portfolio Manager program. Access to Portfolio Manager can be obtained by contacting the Sustainable INL program. The Guiding Principles for Sustainable Existing Buildings is provided in Attachment B.

\subsubsection{Leased Buildings}

Leased buildings can be treated as either new construction or existing buildings. EO 13514

Sec 1 (g) (iii) addresses leased buildings similar to existing buildings as follows:

"Ensuring that at least 15 percent of agency's existing buildings (above 5,000 $\mathrm{ft}^{2}$ ) and building leases (above 5,000 ft ${ }^{2}$ ) meet the Guiding Principles by fiscal year 2015 and that the agency makes annual progress toward 100\% conformance with the Guiding Principles for its building inventory."

For leased buildings, there are two options for compliance with the Guiding Principles:

\section{OPTION L-1}

An agency can demonstrate that a building is compliant with the appropriate set of Guiding Principles (provided in Attachment B)

\section{OPTION L-2}

At any point, the building has been third-party certified to meet the requirements of a multi-attribute green building standard or rating system develop by an ANSI-accredited organization.

Note that the preferred INL method for new construction leases is achieving a minimum of LEED NC-Gold certification. The preferred INL method for a new lease of an existing building or renewing an existing lease is a graded approach to implementing the Guiding Principles.

For new construction leases, the requirement is the same as for DOE-owned new construction projects. Also, as EO 13514 requires all new building starts must be net zero facilities beginning in FY 2020, all new construction leases must plan for net-zero design.

When considering a new construction lease, the preferred rating system is LEED NC. However, it is certainly possible that other LEED rating systems can apply. In the case where LEED for Core and Shell has been used to certify the building, it is recommended to request that the owner finish the building to earn LEED for Commercial Interiors certification before occupying to help ensure that tenant improvements are made using sustainable design principles consistent with the rest of the building. For more information on the LEED rating systems, refer to Section 5.2.

For new leases of existing buildings, INL will include language to show preference for a LEED Gold certified facility and/or require the Guiding Principles on a graded approach depending on factors such as length of the lease and size or significance of the facility.

First, the lease solicitations should indicate a preference for contracts that will provide a LEED Gold certified facility. However, at a minimum, lease solicitations for existing buildings must include provisions that all practical Guiding Principle related upgrades be incorporated prior to INL occupancy. This preference will be evident through a grading system that encourages LEED certification and/or Guiding Principle upgrade as part of the overall solicitation process and provides additional points for designs that will meet either LEED Gold criteria or the Guiding Principles. 
INL managers evaluating space options for larger long-term leased facilities must work with their procurement representative to ensure that new lease solicitations include criteria to meet the Guiding Principles and shows preference for LEED Gold certification. Larger, long-term facilities are typically over 5,000 $\mathrm{ft}^{2}$ and have the potential to become a "permanent" part of the INL facility inventory. The following is sample language to be added to the solicitation:

"II. Section 2, "Executive Order 13423 Guiding Principles," is added to the Statement of Work (SOW) and includes the following verbiage:

$2 \quad$ The "facility," to include all buildings and/or structures, shall be designed and constructed in accordance with requirements from the Executive Order 13423, "Guiding Principles of the Federal Leadership in High Performance and Sustainable Buildings Memorandum of Understanding, " which includes the following criteria:

- Employment of integrated design principles

- Optimization of energy efficiency and use of renewable energy

- Protection and conservation of water

- Enhancement of indoor environmental quality

- Reduction of environmental impacts of materials.

III. The following is added to SOW Section 7, "Submittals":

Within 6 weeks of award, the Lessor shall submit for BEA review and concurrence, a plan identifying how it will meet or exceed the requirements of the Executive Order 13423, "Guiding Principles of the Federal Leadership in High Performance and Sustainable Buildings Memorandum of Understanding."

$I V$. Reference Section 2.2 of the SFO document. Item A, "Building Design," is changed from 400 points available to 300. Item $C$, "Experience and Capabilities," is changed from 100 points available to 50 . Item D is added, and includes the following:

D. Leadership in Environment Design (LEED) Certification:

\section{Total Points Available}

The offeror shall submit with its offer its intent to achieve LEED certification on the facility design and construction, for the version of LEED Green Building Rating System the offeror has selected.

The award of points shall be:

LEED Gold: 150 points

LEED Silver: $\quad 75$ points

LEED Certified: 25 points.

The SOW shall be revised at award to include the successful offerors proposed version of LEED certification.

b. Note that the points available are used by INL for rating proposals; these are not LEED points towards certification. 
V. Reference SFO document, Item "3.4.3.6" is renumbered to "3.4.3.7" and new

Item "3.4.3.6" entitled "LEED Certification" is added and includes the

following verbiage: "3.4.3.6.1. The offeror shall submit with its offer a

preliminary LEED checklist for the version of LEED Green Building Rating

System the offeror has selected."

Note that this language provides one method of showing a preference for LEED Gold and can be revised to simply request a LEED Gold facility with no applicable grading criteria. This process is ongoing and every effort should be made to reasonably request LEED Gold facilities for INL occupancy.

INL managers evaluating space options for smaller short-term or temporary leased facilities must work with the Sustainable INL program and with their procurement representative to ensure that new lease packages include provisions for a facility walkthrough and the implementation of identified practical upgrades relating to the Guiding Principles prior to INL occupancy. Smaller, short-term leased facilities are typically those leased on a temporary basis with little or no possibility of becoming a "permanent" part of the INL facility inventory.

\subsection{Project Management}

It is important to acknowledge an additional, not previously mentioned DOE order that addresses high performance buildings. Requirement 14 in the Contractor Requirements Document of DOE O 413.3B, "Program and Project Management for the Acquisition of Capital Assets," states that "High performance sustainable building principles in accordance with EO 13423, Section 2(f), must be applied to the siting, design, construction, and commissioning of new facilities and major renovations of existing facilities. At a minimum, all new construction and major renovations must meet U.S. Green Building Council's Leadership in Energy and Environmental Design (LEED) Gold certification absent an approved waiver from the Acquisition Executive." This order supports the INL preferred method of documenting the Guiding Principles in new construction by certification to LEED NC-Gold. The companion guide, DOE Guide 413.3-6A, "High Performance Sustainable Building," identifies a number of suggested approaches for achieving a high performance sustainable building (2011).

\subsection{Federal Procurement Guidelines}

The sustainable acquisition requirements for Federal procurement are included in EO 13514, EO 13423, the Federal Leadership in High Performance and Sustainable Buildings Memorandum of Understanding (2006), and the Guiding Principles. Both EO 13514 and EO 13423 flow down to DOE O 436.1, the DOE SSPP, the INL SSP, and the INL PEMP. The Guiding Principles lists seven sustainable acquisition requirements and are flowed down to INL through DOE Order 436.1, DOE SSPP, the INL SSP, and INL PEMP. The Guiding Principles are included in Attachment B for more information.

EO 13514, Sec. 2(h), addresses sustainable acquisition as follows:

“95 percent of new contract actions including task and delivery orders, for products and services with the exception of acquisition of weapon systems, are energy-efficient (Energy Star or Federal Energy Management Program (FEMP)designated), water-efficient, biobased, environmentally preferable (e.g., Electronic Product Environmental Assessment Tool (EPEAT) certified), non-ozone depleting, contain recycled content, or are non-toxic or less toxic alternatives, where such products and services meet agency performance requirements"

EO 13423, Sec 2.(d) and Sec. 2.(f), address sustainable acquisition as follows:

“(i) use of sustainable environmental practices, including acquisition of biobased, environmentally preferable, energy-efficient, water-efficient, and recycled-content products" and (ii) use of paper of at least 30 percent post-consumer fiber content; 
“... ensure that (i) new construction and major renovation of agency buildings comply with the Guiding Principles for Federal Leadership in High Performance and Sustainable Buildings set forth in the Federal Leadership in High Performance and Sustainable Buildings Memorandum of Understanding (2006), and (ii) 15 percent of the existing Federal capital asset building inventory of the agency as of the end of fiscal year 2015 incorporates the sustainable practices in the Guiding Principles."

Federal Leadership in High Performance and Sustainable Buildings Memorandum of Understanding (2006) addresses the Guiding Principles as follows:

"The Guiding Principles are set forth and include

1. Employment of integrated design principles

2. Optimization of energy efficiency and use of renewable energy

3. Protection and conservation of water

4. Enhancement of indoor environmental quality, and

5. Reduction of environmental impacts of materials"

"Agencies will strive to incorporate and adopt, as appropriate and practical, the attached Guiding Principles into existing agency policy and guidance within 180 days of signature. To assist with this effort, the Interagency Sustainability Working Group (ISWG) will provide technical guidance and updates for the Guiding Principles."

Documentation of the Guiding Principles for Sustainable Existing Buildings is typically accomplished through the Federal High Performance Sustainable Buildings Checklist:

"The purpose is to assist Federal agencies with assessing their existing building stock against the Guiding Principles for Sustainable Existing Buildings, and for reporting on the sustainability data element of the Federal Real Property Profile (FRPP)."

"The Federal High Performance Sustainable Buildings Checklist represents collaboration between EPA's ENERGY STAR Program, DOE's Federal Energy Management Program, and the General Services Administration."

"Guiding Principles for Sustainable Existing Buildings:

1. Employ Integrated Assessment, Operation, \& Management Principles (Integrated 1, Integrated 2, Integrated 3, Integrated 4, Commission 1)

2. Optimize Energy Performance (Energy Efficiency 1, Energy Efficiency 2, Renewable 1, Measurement 1, Benchmark 1)

3. Protect and conserve water (Indoor Water 1, Outdoor Water 1, Storm Water 1, Water Products 1)

4. Enhance Indoor Environmental Quality (Ventilation 1, Moisture 1, Lighting 1, Lighting 2, Low Emit 1, Pest 1, Tobacco 1)

5. Reduce Environmental Impact of Materials (Recycle 1, Biobased 1, Environmentally Preferred 1, Waste 1, Ozone 1)"

The Guiding Principles for Sustainable New Construction and Major Renovations, and the Guiding Principles for Sustainable Existing Buildings address Sustainable Acquisition as follows:

- Optimize Energy Performance (Energy Efficiency - Use Energy Star and FEMP-designated Energy Efficient Products, where available)

- Protect and conserve water (Indoor Water and Water Efficient Products - Specify EPA's WaterSense-labeled products or other water conserving products, where available) 
- Enhance Indoor Environmental Quality (Low Emitting Materials - Specify materials and products with low pollutant emissions. Use low emitting materials for building modification, maintenance, and cleaning. Integrated Pest Management - Use EPA-registered pesticides only when needed.)

- Reduce Environmental Impact of Materials (Recycled Content, Biobased Content, Environmentally Preferred Products, and Ozone Depleting Compounds)

DOE O 436.1 "Departmental Sustainability," addresses Sustainable Acquisition as follows:

"Contains requirements that DOE will accomplish to implement EO 13514 and EO 13423"

"Ensure that DOE achieves sustainability goals established in its SSPP."

INL Sustainable Acquisition requirements and actions are defined annually in the SSPP, INL SSP and current PEMP. Contact the Sustainable INL Program for the latest version of these documents.

In addition to meeting the federal and DOE high performance sustainable building requirements, it is important to remember that federal guidelines require purchasing designated environmentally preferable construction products, including procure designated green products with specific sustainable attributes that contain biobased and/or recycled content, comply with ENERGY STAR/FEMP and/or EPEAT standards, and/or are environmentally preferable, nontoxic, non-ozone depleting, and/or water efficient.

Preference is given to the designated product unless the following conditions exist:

1. Life-cycle cost of the designated product is unreasonable

2. Designated product does not meet performance specifications

3. Designated product is not produced with specified attribute or not available competitively within a reasonable time frame.

The sustainable acquisition clauses have been included in the General Provisions located at the INL external website:

\section{https://inlportal.inl.gov/portal/server.pt/community/procurement/346/documents and forms}

Note: Scroll down to the Current General Provision section and select the pdf link to PROC-202 and to Article A.5.

For more information, including a full list of designated green products for federal procurement, explore the Green Products Compilation at:

http://sftool.gov/greenprocurement?CFID $=108518 \&$ CFTOKEN $=42165006$ 


\section{FINANCIAL INCENTIVES}

How much high performance sustainable buildings cost and whether they cost more than conventional construction are usually the first questions asked. While there are no straightforward answers to these questions since each project is unique, various studies have shown that green buildings typically have lower operation and management (O\&M) costs; thus, the potential higher capital costs are offset in only a few years.

Many studies have been undertaken to quantify the price difference of a building with high performance features versus the building without these features.

A study done for the state of California looked at the cost of 33 green buildings compared to the conventional, non-green design of the same buildings (Kats et al., 2003). This study found that the average premium for a green building was less than $2 \%$ (or $\$ 3-5 /$ square foot) more than the conventional design. This increase was mostly attributed to increased architectural and engineering support. The total life-cycle savings (including energy, water, waste, and improved productivity and health) were found to be 10 times the average initial investment for design and construction.

In fact, new buildings designed to be energy efficient can operate on $20 \%$ of the energy used by corresponding older existing facilities (for corresponding energy savings of 80\%) (Capehart et al., 2006). Older existing facilities can usually be retrofit to save around $30 \%$ of the existing energy used (Capehart et al., 2006). Clearly, adopting energy efficient design features into new building designs and retrofit projects will provide direct O\&M cost savings and improved life-cycle costs.

In 2004, Davis Langdon, a cost planning and sustainable design management firm, conducted an in-depth study and found that construction costs varied greatly within the same building type (academic buildings, laboratories, and libraries), but that there was no statistically significant difference between the construction cost of a LEED certified building and a non-LEED certified building (Matthiessen and Morris 2004). A follow-up study completed by the same authors in 2007 came to the same conclusion (Matthiessen and Morris 2007). A graph comparing the cost of non-LEED buildings to LEED buildings for their sample of laboratory buildings is shown in Figure 1. These results are indicative of their findings for other building types as discussed above.

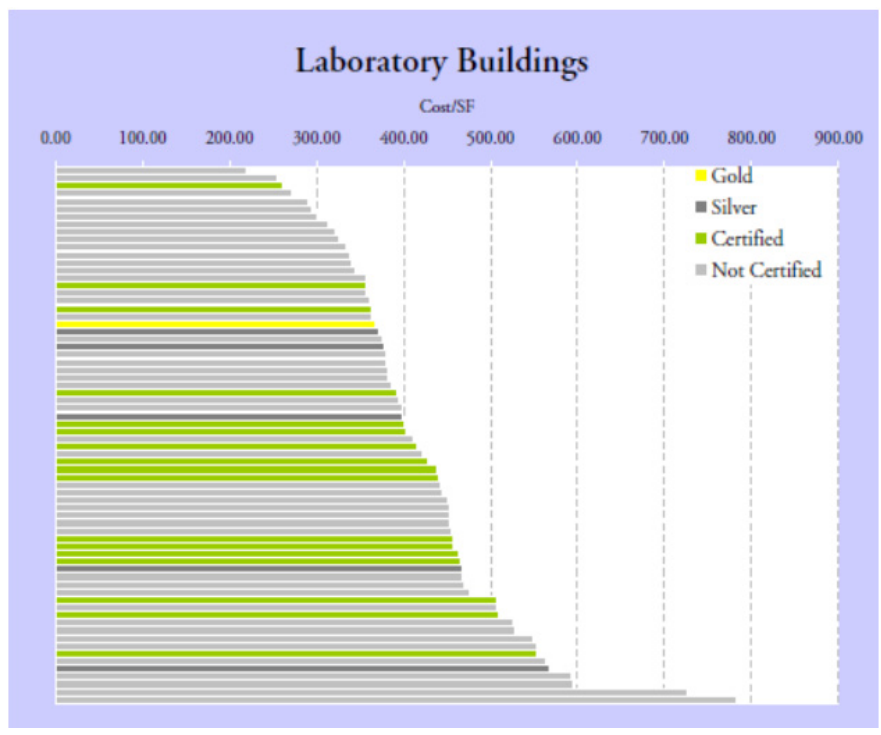

Figure 1. Cost comparison of non-LEED laboratory buildings to LEED laboratory buildings (Matthiessen and Morris 2007). 
During the design and construction of the Center for Advanced Energy Studies (CAES) building, a cost report was prepared to evaluate the additional cost of pursuing LEED certification. The total cost for LEED (documentation and certification fees) and high performance design and construction measures (design and process costs) are estimated to be $\$ 193,100$; however, note that the contractor stated that they saw no additional costs associated with green building design strategies incorporated in the building. The current payback for the increased design and construction rigor is 3.2 years with a projected return on investment of $30 \%$ due to $\$ 58,854$ in annual energy savings (Baker 2008).

There are two significant factors when determining the extent of whether high performance and/or LEED buildings will have a higher premium over conventional construction:

1. When the sustainable building goals are identified. Sustainable goals identified during a project's design phase (preferably during a design charrette with all of the stakeholders involved) can be integrated with little or no additional cost, while goals identified once the construction document phase has begun may require costly change orders.

2. The experience level of the design team. High performance buildings and the LEED certification process as a whole have a learning curve, which means an experienced design team using an integrated design process will succeed more often and with lower costs than an inexperienced team. (This is discussed further in Best Practices, Section 6, as well as Attachment C, "Hiring the Right Team" [Betterbricks 2007] and Attachment D, "Integrated Design Steps for Designers"

[Betterbricks]). As a result, INL staff members and contractors are encouraged to obtain sustainable design and/or LEED training.

Two significant benefits of high performance buildings that must be considered when discussing their financial incentives are higher productivity and reduced absenteeism of the building occupants; high performance buildings that focus on indoor environmental quality features (see Section 5.2 for further discussion) provide a more comfortable and healthy work environment for their occupants. A study comparing the employee performance at two companies before and after they moved into LEED certified buildings observed an increase in employee productivity of $2 \%$ or nearly 40 hours per employee over a year (Singh \& Syal 2009). This is an important payback to consider when evaluating the full life-cycle cost of a high performance building since the salaries of the building occupants account for a much larger annual budget than the traditional O\&M costs, and thus can greatly lower a building's return on investment. Occupancy comfort and health are also important considerations when the goal is to attract and retain the best people at INL.

Despite the potential of slightly higher capital costs, high performance buildings can yield O\&M savings and improved employee productivity that can easily pay back this cost within a few years. This life-cycle cost benefit is critical to the future of INL. 


\section{STRATEGY}

This revised High Performance Building Strategy has been aligned with DOE Order 436.1 and the SSPP and employs two levels: the Guiding Principles and LEED Gold certification. The first level identifies the requirements of the Guiding Principles, and the second level outlines the LEED certification process and recommends which credits should be met when LEED Gold certification is required.

The recommended review cycle is annually for this document or as needed to stay up to date with the most recent executive and DOE orders, as well as the latest versions of the Guiding Principles, LEED rating systems, and the relevant INL programs. If new guidance, including executive and DOE orders, is incorporated into INL's contract and this new guidance supersedes any of the contents in this document, then the new guidance should take precedence.

\subsection{Guiding Principles}

Per EO 13423 and the SSPP, the "Guiding Principles for Federal Leadership in High Performance and Sustainable Buildings" (referred to as the Guiding Principles) are divided into two sections to address new and existing buildings.

1. The Guiding Principles for Sustainable New Construction and Major Renovations must be met for all new building construction, all new Agency Leased buildings, and all major renovations of buildings greater than $5,000 \mathrm{ft}^{2}$.

2. At least $15 \%$ of the existing building inventory (owned and leased) over $5,000 \mathrm{ft}^{2}$ must meet the Guiding Principles for Sustainable Existing Buildings by FY 2015 with an ongoing goal of meeting the Guiding Principles in $100 \%$ of the Existing Building inventory.

See Attachment B for a copy of the Guiding Principles (ISWG 2008). The Guiding Principles can also be accessed at http://www.wbdg.org/references/fhpsb new.php.

DOE proposed additional HPSB equivalencies in its 2012 SSPP submission to consider buildings meeting the following criteria as complying with the Guiding Principles. Any building that:

- Achieves LEED-Existing Buildings (EB) Silver or higher

- Achieves LEED-New Construction (NC) Gold or higher

- Achieves a Green Globes-NC rating of four

- Achieves a Green Globes Continual Improvement of Existing Buildings (CIEB) rating of three

- Is occupied for more than 1 year that achieves Living Status designation by the Living Building Challenge.

As stated earlier, the INL preference is to obtain LEED-NC Gold for all new construction and agency leased buildings and document the Guiding Principles for Sustainable Existing Buildings met in owned and lease buildings.

Two specific requirements from the SSPP and DOE Order 13514, respectively, must be adhered to regardless of the High Performance Building pathway taken:

- Ensure all new construction is designed at 30\% more energy efficient that the baseline established by ANSI/ASHRAE/IESNA Standard 90.1

- Design all new federal buildings to achieve net zero energy use, beginning in FY 2020. 


\subsection{LEED $^{\circledR}$}

LEED certification is the INL preferred industry standard for validating the high performance and sustainable design and construction of new buildings, including the surrounding site. A number of LEED rating systems are available for specific buildings types and/or applications. The most applicable rating systems are discussed here, with the primary one being LEED for New Construction, and the secondary rating systems being LEED for Existing Buildings: Operations and Maintenance, LEED for Core and Shell, and LEED for Commercial Interiors.

The LEED NC rating system is intended for new construction and major renovations of commercial and institutional projects, with a focus on office buildings. Practitioners have also applied the system to data centers, manufacturing plants, laboratories, and many other building types. A copy of a blank checklist for LEED NC is contained in Attachment E, "Checklist for LEED for New Construction."

LEED for Existing Buildings: Operations and Maintenance (EB O\&M) is a system for maximizing best operational practices, monitoring systems' performance, and optimizing resources through exemplary maintenance. LEED EB O\&M focuses primarily on operations and materials usage, but also includes building performance requirements. A copy of a blank checklist for LEED EB O\&M can be found in Attachment F.

As the name implies, the LEED Core and Shell (CS) rating system focuses on a CS and is a good choice for buildings that will have larger internal process loads or uncertain occupancy and use (e.g., multiple occupants). Laboratories and fabrication facilities would be good candidates for LEED CS. This rating system would generally not apply for INL, but it may be applicable should INL lease a building where INL does not have the primary occupancy and use. A copy of a blank checklist for LEED CS is contained in Attachment G, "Checklist for LEED for Core and Shell."

The LEED for Commercial Interiors (CI) rating system is intended for tenant improvements to ensure green interiors are designed following sustainable principles. It can be used for buildings that have already been certified under LEED CS. A copy of a blank checklist for LEED CI is contained in Attachment H, "Checklist for LEED for Commercial Interiors."

Each LEED rating system measures the building's sustainable performance by focusing on the following five areas of sustainable design:

- Sustainable Sites. Geared towards minimizing site disturbance; using responsible landscaping; promoting the use of commuting and alternative transportation such as bicycles, mass transit, and alternatively fueled vehicles; and reducing light pollution.

- Water Efficiency. Covers design features that reduce potable water consumption and/or wastewater treatment demand.

- Energy and Atmosphere. Promotes energy efficiency and renewable energy consumption.

- Materials and Resources. Calls for efficient material use through the specification of recycled, rapidly renewable, salvaged, and local building materials during design and the recycling of building waste during construction and occupancy. The goal is to minimize the demand for virgin materials and the harmful environmental effects associated with extracting and processing them, while lowering the total embodied energy content of the building.

- Indoor Environmental Quality. Promotes the health and productivity of building occupants by providing well-ventilated and thermally comfortable interior spaces, materials that do not off-gas, and daylight and views. 
Two additional categories, Innovation in Design and Regional Priority, give the project team flexibility. The first category gives credit for exceeding an established LEED parameter or using sustainable building practices not yet recognized in LEED, and the second allows for additional points for green building strategies that address an environmental problem with regional significance such as water shortages. Available points are based on the project location as determined by zip code.

Each category contains a number of subcategories or credits. One or more points are earned for each credit that is met; some credits are further divided to offer additional points for meeting a parameter(s) beyond, or in addition to, the initial measurable accomplishment. One Hundred possible points are available for the five main categories of sustainable design with an additional 10 points possible from the two additional categories. There are four award levels for all LEED 2009 rating system certifications, including $\mathrm{NC}, \mathrm{CS}, \mathrm{EB}$ O\&M, and CI:

- $\quad$ Certified (40-49 points)

- $\quad$ Silver (50-59 points)

- $\quad$ Gold (60-79 points)

- Platinum (80 points and above).

The USGBC considers a number of building practices essential to green building and has made them prerequisites for LEED certification. These prerequisites are baseline requirements for buildings pursuing LEED certification, and they do not add points towards certification.

The LEED NC checklist in Table 3 is a recommended guide for buildings particular to INL. This checklist provides assistance in identifying the credits that are most easily and effectively captured for buildings in the southeast Idaho climate and energy region based on the existing services available and INL's unique environmental and economic challenges (i.e., inexpensive electric energy and high desert climate). The LEED NC checklist has been customized for this document to identify the LEED credits that also satisfy the Guiding Principles in addition to the recommended credits to achieve LEED Gold. Refer to the comments (blue text) following each credit for more information. In addition, the following key (Table 3) will assist with understanding the headings used for the first four columns in the checklist below in Table 4.

Table 3. Key for recommended LEED NC checklist to use as a guide at INL.

\begin{tabular}{|l|l|l|}
\hline $\begin{array}{c}\text { Strategy } \\
\text { Level }\end{array}$ & $\begin{array}{c}\text { Likelihood of } \\
\text { Achieving } \\
\text { Credit }\end{array}$ & \\
\hline GP & Y or N & Indicates whether the credit is also applicable to the Guiding Principles. \\
\hline LEED & Yes & $\begin{array}{l}\text { This credit is required per the Guiding Principles, or considered very reasonable to } \\
\text { achieve (low impact to project cost and/or design) and should therefore be pursued } \\
\text { toward satisfying LEED Gold. There are currently 64 points identified in this group, } \\
\text { slightly exceeding the minimum for LEED Gold. It is recommended that additional } \\
\text { credits from the possible ('?") category be incorporated into the design in case } \\
\text { changes are made that make achievement of some credits difficult or impossible. }\end{array}$ \\
\hline LEED & $?$ & $\begin{array}{l}\text { The possibility of satisfying this credit's requirements will vary depending on the } \\
\text { building location (Site, town, etc.) and the goals of the project team. Any points } \\
\text { received from these credits would be added to the "Yes" category. It is } \\
\text { recommended that additional credits from this category be achieved to ensure LEED } \\
\text { Gold certification. }\end{array}$ \\
\hline LEED & No & $\begin{array}{l}\text { It is not likely to achieve this credit for a number of reasons including the building } \\
\text { design and/or location characteristics, availability of services in this region, and the } \\
\text { cost effectiveness of implementing the credit. }\end{array}$ \\
\hline
\end{tabular}


Table 4. Recommended LEED NC checklist to use as a guide at INL.

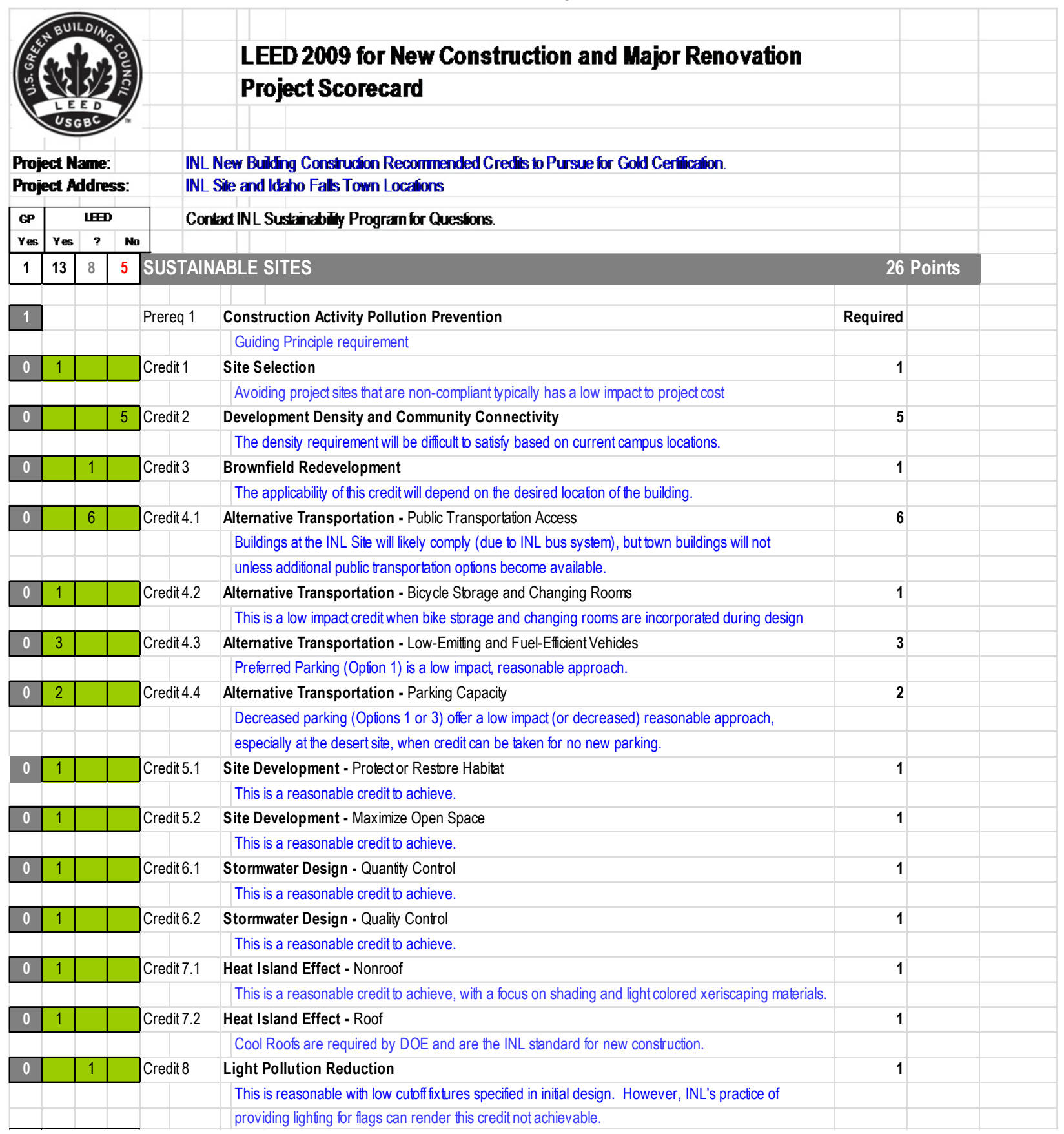




\begin{tabular}{|c|c|c|c|c|c|c|c|c|}
\hline & & & & & \multicolumn{2}{|r|}{ LEED 2009 for New Construction and Major Renovation } & & \\
\hline & & & & & \multicolumn{2}{|c|}{ Project Scorecard } & & \\
\hline \multirow{3}{*}{\multicolumn{4}{|c|}{$\begin{array}{l}\text { Project Name: } \\
\text { Project Address: }\end{array}$}} & \multirow{2}{*}{\multicolumn{3}{|c|}{ INL New Building Construction Recommen ded Credits to Pursue for Gold Cerfifcation. }} & & \\
\hline & & & & & & & & \\
\hline & & & & \multicolumn{3}{|c|}{ INL Site and Idaho Falls Town Locations } & & \\
\hline GP & \multicolumn{3}{|c|}{ LEED } & \multicolumn{3}{|c|}{ ContactINL Sustainability Program for Questions. } & & \\
\hline$Y_{e s}$ & Yes & $?$ & No & & & & & \\
\hline 3 & 6 & 4 & 0 & \multicolumn{3}{|c|}{ WATER EFFICIENCY } & \multicolumn{2}{|c|}{10 Points } \\
\hline \multirow[t]{2}{*}{1} & & & & Prereq 1 & \multicolumn{2}{|c|}{ Water Use Reduction (Reduce by $20 \%$ ) } & Required & \\
\hline & & & & & \multicolumn{2}{|c|}{ Guiding Principle requirement. } & & \\
\hline \multirow[t]{5}{*}{1} & 2 & 2 & & Credit 1 & \multicolumn{2}{|c|}{ Water Efficient Landscaping } & 2 to 4 & \\
\hline & & & & & & Reduce by $50 \%$ & 2 & \\
\hline & & & & & \multicolumn{2}{|c|}{ Guiding Principle requirement. } & & \\
\hline & & & & & & No Potable Water Use for Irrigation & 4 & \\
\hline & & & & & This & credit is possible with careful landscape design and/or use of process water. & & \\
\hline \multirow[t]{2}{*}{0} & & 2 & & Credit2 & \multicolumn{2}{|r|}{ Innovative Wastewater Technologies } & 2 & \\
\hline & & & & & Optio & $\mathrm{n} 1$ is possible with careful design and incorporation of appropriate technologies. & & \\
\hline \multirow[t]{6}{*}{1} & 4 & & & Credit 3 & \multicolumn{2}{|c|}{ Water Use Reduction } & 2 to 4 & \\
\hline & & & & & $\mathrm{Y}$ & Reduce by $30 \%$ & 2 & \\
\hline & & & & & $\mathrm{Y}$ & Reduce by $35 \%$ & 3 & \\
\hline & & & & & $\mathrm{Y}$ & Reduce by $40 \%$ & 4 & \\
\hline & & & & & \multicolumn{2}{|r|}{ Use of low flow fixtures (i.e.: EPA WaterSense) is required by the Guiding Principles, EO 13514 , } & & \\
\hline & & & & & \multicolumn{2}{|c|}{ and federal procurement regulations. } & & \\
\hline
\end{tabular}




\begin{tabular}{|c|c|c|c|c|c|c|c|c|}
\hline & & & & & \multicolumn{2}{|r|}{ LEED 2009 for New Construction and Major Renovation } & & \\
\hline & & & & & \multicolumn{2}{|c|}{ Project Scorecard } & & \\
\hline \multirow{2}{*}{\multicolumn{4}{|c|}{ Project Name: }} & \multirow{2}{*}{\multicolumn{3}{|c|}{ INL New Building Constuction Recommended Credits to Pursue for Gold Cerfication. }} & & \\
\hline & & & & & & & & \\
\hline \multicolumn{4}{|c|}{ Project Address: } & & \multicolumn{2}{|c|}{ INL Site and Idaho Falls Town Locations } & & \\
\hline GP & \multicolumn{3}{|c|}{ LEED } & & \multicolumn{2}{|c|}{ Contact INL Sustainability Program for Questions. } & & \\
\hline$Y_{e s}$ & Yes & $?$ & No & & & & & \\
\hline 5 & 17 & 12 & 6 & \multicolumn{3}{|c|}{ ENERGY \& ATMOSPHERE } & \multicolumn{2}{|c|}{35 Points } \\
\hline \multirow[t]{2}{*}{1} & & & & Prereq 1 & \multicolumn{2}{|r|}{ Fundamental Commissioning of Building Energy Systems } & Required & \\
\hline & & & & & Guid & ing Principle requirement & & \\
\hline \multirow[t]{2}{*}{0} & & & & Prereq 2 & Minim & um Energy Performance (Improve by 10\% for New Buildings or 5\% for Existing) & Required & \\
\hline & & & & & The & minimum energy performance does not meet the $30 \%$ goal in the Guiding Principles. & & \\
\hline 1 & & & & Prereq & Funda & amental Refrigerant Management & Required & \\
\hline & & & & & Guid & ing Principle requirement & & \\
\hline 1 & 10 & 9 & & Credit 1 & Optim & ize Energy Performance & 1 to 19 & \\
\hline & & & & & & Improve by $12 \%$ for New Buildings or $8 \%$ for Existing Building Renovations & 1 & \\
\hline & & & & & & Improve by $14 \%$ for New Buildings or $10 \%$ for Existing Building Renovations & 2 & \\
\hline & & & & & & Improve by $16 \%$ for New Buildings or $12 \%$ for Existing Building Renovations & 3 & \\
\hline & & & & & & Improve by $18 \%$ for New Buildings or $14 \%$ for Existing Building Renovations & 4 & \\
\hline & & & & & $\mathrm{Y}$ & Improve by $20 \%$ for New Buildings or $16 \%$ for Existing Building Renovations & 5 & \\
\hline & & & & & $\mathrm{Y}$ & Improve by $22 \%$ for New Buildings or $18 \%$ for Existing Building Renovations & 6 & \\
\hline & & & & & $\mathrm{Y}$ & Improve by $24 \%$ for New Buildings or $20 \%$ for Existing Building Renovations & 7 & \\
\hline & & & & & $\mathrm{Y}$ & Improve by $26 \%$ for New Buildings or $22 \%$ for Existing Building Renovations & 8 & \\
\hline & & & & & $\mathrm{Y}$ & Improve by $28 \%$ for New Buildings or $24 \%$ for Existing Building Renovations & 9 & \\
\hline & & & & & $\mathrm{Y}$ & Improve by $30 \%$ for New Buildings or $26 \%$ for Existing Building Renovations & 10 & \\
\hline & & & & & Min & imum of 30\% efficiency improvement required by the Guiding Principles. & & \\
\hline & & & & & & Improve by $32 \%$ for New Buildings or $28 \%$ for Existing Building Renovations & 11 & \\
\hline & & & & & & Improve by $34 \%$ for New Buildings or $30 \%$ for Existing Building Renovations & 12 & \\
\hline & & & & & $?$ & Improve by $36 \%$ for New Buildings or $32 \%$ for Existing Building Renovations & 13 & \\
\hline & & & & & $?$ & Improve by $38 \%$ for New Buildings or $34 \%$ for Existing Building Renovations & 14 & \\
\hline & & & & & $?$ & Improve by $40 \%$ for New Buildings or $36 \%$ for Existing Building Renovations & 15 & \\
\hline & & & & & & Improve by $42 \%$ for New Buildings or $38 \%$ for Existing Building Renovations & 16 & \\
\hline & & & & & $?$ & Improve by $44 \%$ for New Buildings or $40 \%$ for Existing Building Renovations & 17 & \\
\hline & & & & & $?$ & Improve by $46 \%$ for New Buildings or $42 \%$ for Existing Building Renovations & 18 & \\
\hline & & & & & $?$ & Improve by $48 \%+$ for New Buildings or $44 \%+$ for Existing Building Renovations & 19 & \\
\hline 1 & & 1 & 6 & ]Credit 2 & On-Si & te Renewable Energy & 1 to 7 & \\
\hline & & & & & & $1 \%$ Renewable Energy & 1 & \\
\hline & & & & & This & is referenced indirectly in the Guiding Principles when specifying meeting 30\% of hot water & & \\
\hline & & & & & deme & and with installation of solar water heating. Since $3 \%$ of the average commercial building's & & \\
\hline & & & & & ener & gy use is for water heating, this yields an overall guideline for $1 \%$ renewable energy. & & \\
\hline & & & & & Sola & $r$ water heating is encouraged, but must be cost effective and provide payback within the life of & & \\
\hline & & & & & the in & nstalled equipment. & & \\
\hline & & & & & & $3 \%$ Renewable Energy & 2 & \\
\hline & & & & & & $5 \%$ Renewable Energy & 3 & \\
\hline & & & & & & $7 \%$ Renewable Energy & 4 & \\
\hline & & & & & & 9\% Renewable Energy & 5 & \\
\hline & & & & & & $11 \%$ Renewable Energy & 6 & \\
\hline & & & & & & 13\% Renewable Energy & 7 & \\
\hline 0 & 2 & & & Credit 3 & Enhan & iced Commissioning & 2 & \\
\hline & & & & & Enha & anced Commissioning is a incremental increase in Commissioning activities that will provide & & \\
\hline & & & & & adde & d value to the project. It is a reasonable credit to pursue. & & \\
\hline 0 & & 2 & & Credit 4 & Enhan & ced Refrigerant Management & 2 & \\
\hline & & & & & This & credit is possible with careful equipment selection and the use of alternative refrigerants. & & \\
\hline 1 & 3 & & & Credit5 & Measu & rement and Verification & 3 & \\
\hline & & & & & The & Guiding Principles require building level energy metering (electricity and natural gas) and a one- & & \\
\hline & & & & & year & benchmarking to the EPA Porffolio Manager database at a minimum. & & \\
\hline 0 & 2 & & & Credit 6 & Green & Power & 2 & \\
\hline & & & & & INL $p$ & purchases locally generated Renewable Energy Certificates (RECs) at $10 \%$ of the INL total & & \\
\hline & & & & & electr & ric energy use. This purchase counts toward Green Power usage. & & \\
\hline
\end{tabular}




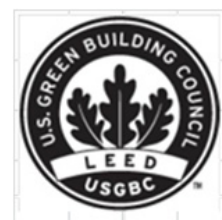

\section{LEED 2009 for New Construction and Major Renovation Project Scorecard}

Project Name: Project Address:

INL New Building Construction Recommen ded Credits to Pursue for Gold Cerfication.

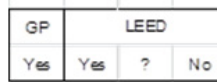
INL Site and Idaho Falls Town Locations

\begin{tabular}{l|l|l|l|l|}
\hline 3 & 6 & 8 & 0 & MATERIALS \& RESOURCES
\end{tabular}

\begin{tabular}{|c|c|c|c|c|c|}
\hline 1 & & & Prereq 1 & Storage and Collection of Recyclables & Required \\
\hline 0 & & 3 & Credit 1.1 & Building Reuse - Maintain Existing Walls, Floors and Roof & 1 to 3 \\
\hline & & & & This credit will typically be applied to a renovation project rather than a new construction project. & \\
\hline & & & & $?$ Reuse $55 \%$ & 1 \\
\hline & & & & $?$ Reuse $75 \%$ & 2 \\
\hline & & & & $?$ Reuse 95\% & 3 \\
\hline 0 & & 1 & Credit 1.2 & Building Reuse - Maintain Interior Nonstructural Elements & 1 \\
\hline & & & & This credit will typically be applied to a renovation project rather than a new construction project. & \\
\hline 1 & 1 & 1 & Credit 2 & Construction Waste Management & 1 to 2 \\
\hline & & & & The Guiding Principles require a minimum of $50 \%$ diversion. The additional credit for $75 \%$ diversion & \\
\hline & & & & is achievable with careful planning and project management. & \\
\hline & & & & Y $50 \%$ Recycled or Salvaged & 1 \\
\hline & & & & Guiding Principle requirement. & \\
\hline & & & & ? $75 \%$ Recycled or Salvaged & 2 \\
\hline 0 & & 2 & Credit 3 & Materials Reuse & 1 to 2 \\
\hline & & & & This credit is possible with careful design and reuse of furnishings and cubical partitions. & \\
\hline & & & & $?$ Reuse $5 \%$ & 1 \\
\hline & & & & $?$ Reuse $10 \%$ & 2 \\
\hline 1 & 2 & & Credit 4 & Recycled Content & 1 to 2 \\
\hline & & & & Guiding Principle requirement. & \\
\hline & & & & \begin{tabular}{l|l}
$Y$ & $10 \%$ \\
\end{tabular} & 1 \\
\hline & & & & Y $20 \%$ of Content & 2 \\
\hline 0 & 1 & 1 & Credit 5 & Regional Materials & 1 to 2 \\
\hline & & & & This is a reasonable credit to achieve. & \\
\hline & & & & Y $10 \%$ of Materials & 1 \\
\hline & & & & $? 20 \%$ of Materials & 2 \\
\hline 1 & 1 & & Credit 6 & Rapidly Renewable Materials & 1 \\
\hline & & & & Guiding Principle requirement in combination with Credit 7 & \\
\hline Y & 1 & & Credit 7 & Certified Wood & 1 \\
\hline & & & & Guiding Principle requirement in combination with Credit 6 & \\
\hline
\end{tabular}




\begin{tabular}{|c|c|c|c|c|c|c|c|}
\hline & & & & & LEED 2009 for New Construction and Major Renovation & & \\
\hline & & & & & Project Scorecard & & \\
\hline \multirow{2}{*}{\multicolumn{4}{|c|}{ Project Name: }} & \multirow{2}{*}{\multicolumn{2}{|c|}{ INL New Building Construction Recommended Credits to Pursue for Gold Cerfifcation. }} & & \\
\hline & & & & & & & \\
\hline \multicolumn{4}{|c|}{ Project Address: } & \multicolumn{2}{|r|}{ INL Site and Idaho Falls Town Locations } & & \\
\hline GP & \multicolumn{3}{|c|}{ LEED } & \multicolumn{2}{|c|}{ Contact INL Sustainability Program for Questions. } & & \\
\hline Yes & Yes & $?$ & No & & & & \\
\hline 7 & 15 & 0 & 0 & \multicolumn{2}{|c|}{ INDOOR ENVIRONMENTAL QUALITY } & \multicolumn{2}{|c|}{15 Points } \\
\hline \multirow[t]{2}{*}{1} & & & & Prereq 1 & Minimum Indoor Air Quality Performance & Required & \\
\hline & & & & & Guiding Principle requirement. & & \\
\hline \multirow[t]{2}{*}{$\overline{1}$} & & & & Prereq 2 & Environmental Tobacco Smoke (ETS) Control & Required & \\
\hline & & & & & Guiding Principle requirement. & & \\
\hline \multirow[t]{2}{*}{0} & 1 & & & Credit 1 & Outdoor Air Delivery Monitoring & 1 & \\
\hline & & & & & This is a reasonable credit to achieve. & & \\
\hline \multirow[t]{2}{*}{0} & 1 & & & Credit 2 & Increased Ventilation & 1 & \\
\hline & & & & & This is a reasonable credit to achieve. & & \\
\hline \multirow[t]{2}{*}{1} & 1 & & & Credit 3.1 & Construction Indoor Air Quality Management Plan - During Construction & 1 & \\
\hline & & & & & Guiding Principle requirement. & & \\
\hline 1 & 1 & & & Credit 3.2 & Construction Indoor Air Quality Management Plan - Before Occupancy & 1 & \\
\hline & & & & & Guiding Principle requirement. & & \\
\hline 1 & 1 & & & Credit 4.1 & Low-Emitting Materials - Adhesives and Sealants & 1 & \\
\hline & & & & & Guiding Principle requirement - All materials and products in 4.1 - 4.4 & & \\
\hline $\mathrm{Y}$ & 1 & & & Credit 4.2 & Low-Emitting Materials - Paints and Coatings & 1 & \\
\hline & & & & & Guiding Principle requirement - All materials and products in 4.1 - 4.4 & & \\
\hline $\bar{Y}$ & 1 & & & Credit 4.3 & Low-Emitting Materials - Flooring Systems & 1 & \\
\hline & & & & & Guiding Principle requirement - All materials and products in 4.1 - 4.4 & & \\
\hline $\mathrm{Y}$ & 1 & & & Credit 4.4 & Low-Emitting Materials - Composite Wood and Agrifber Products & 1 & \\
\hline & & & & & Guiding Principle requirement - All materials and products in 4.1 - 4.4 & & \\
\hline 0 & 1 & & & Credit 5 & Indoor Chemical and Pollutant Source Control & 1 & \\
\hline & & & & & This is a reasonable credit to achieve. & & \\
\hline 0 & 1 & & & Credit 6.1 & Controllability of Systems - Lighting & 1 & \\
\hline & & & & & This is a reasonable credit to achieve. & & \\
\hline 0 & 1 & & & Credit 6.2 & Controllability of Systems - Thermal Comfort & 1 & \\
\hline & & & & & This is a reasonable credit to achieve. & & \\
\hline 1 & 1 & & & Credit 7.1 & Thermal Comfort - Design & 1 & \\
\hline & & & & & Guiding Principle requirement. & & \\
\hline 0 & 1 & & & Credit 7.2 & Thermal Comfort - Verification & 1 & \\
\hline & & & & & This is a reasonable credit to achieve. & & \\
\hline 1 & 1 & & & Credit 8.1 & Daylight and Views - Daylight & 1 & \\
\hline & & & & & Guiding Principle requirement, although the measurement for daylight is slighty different & & \\
\hline 0 & 1 & & & Credit 8.2 & Daylight and Views - Views & 1 & \\
\hline & & & & & This is a reasonable credit to achieve. & & \\
\hline
\end{tabular}




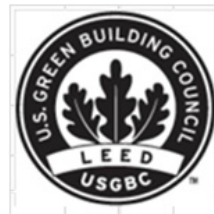

\section{LEED 2009 for New Construction and Major Renovation Project Scorecard}

Project Name:

INL New Building Construction Recommended Credits to Pursue for Gold Cerffication.

Project Address:

INL Site and Idaho Falls Town Locations

\begin{tabular}{|c|c|c|c|}
\hline$G P$ & \multicolumn{3}{|c|}{ LEED } \\
YeS & $Y_{S}$ & $?$ & No \\
\hline \hline 0 & 4 & 2 & 0 \\
\hline
\end{tabular}

ContactINL Sustainability Program for Questions.

\begin{tabular}{l|l|l|l|l}
\hline \hline 0 & 4 & 2 & 0 & INNOVATION IN DESIGN \\
\hline
\end{tabular}

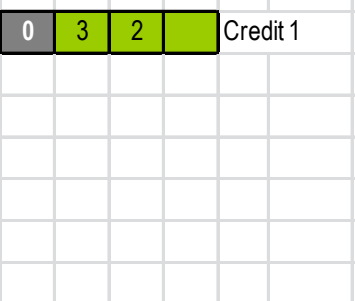

Innovation in Design

1 to 5

Projects should strive to achieve all 5 Innovation points or all 3 Exemplary Performance points..

\begin{tabular}{|c|l|l|}
\hline $\mathrm{Y}$ & Innovation or Exemplary Performance \\
\hline $\mathrm{Y}$ & Innovation or Exemplary Performance \\
\hline $\mathrm{Y}$ & Innovation or Exemplary Performance \\
\hline$?$ & Innovation \\
\hline$?$ & Innovation
\end{tabular}

\section{\begin{tabular}{l|l|l|l|ll}
0 & 1 & & & Credit $2 \quad$ LEED $^{\circledR}$ Accredited Professional
\end{tabular}}

Always include a LEED AP on the integrated design team.

\section{\begin{tabular}{l|l|l|l|l|l}
0 & 3 & 2 & 1 & Credit $1 \quad$ Regional Priority
\end{tabular}}

*Although there are 6 possible regional priority credits to select from, only 4 total points are allowed for regional priority.

Y Regionally Defined Credit Achieved: SSc5.1

This was identified previously as a reasonable credit to achieve.

Y Regionally Defined Credit Achieved: SSc7.1

This was identified previously as a reasonable credit to achieve.

Y Regionally Defined Credit Achieved: SSc5.2

This was identified previously as a reasonable credit to achieve.

? Regionally Defined Credit Achieved: WEc1, Opt. 2

The option to install no potable water for irrigation is possible with careful design and/or the use of process water.

? Regionally Defined Credit Achieved: WEc3(40\%)

A $40 \%$ reduction in Water Use is achievable with careful design and is considered likely at INL.

N Regionally Defined Credit Achieved: EAc2(5\%)

This credit to install Renewable Energy Generation is generally not considered cost effective at INL.

\begin{tabular}{|c|c|c|c|}
\hline GP & \multicolumn{3}{|c|}{ LEED } \\
Yes & Yes & $?$ & No \\
\hline 19 & 64 & 35 & 11 \\
\hline
\end{tabular}

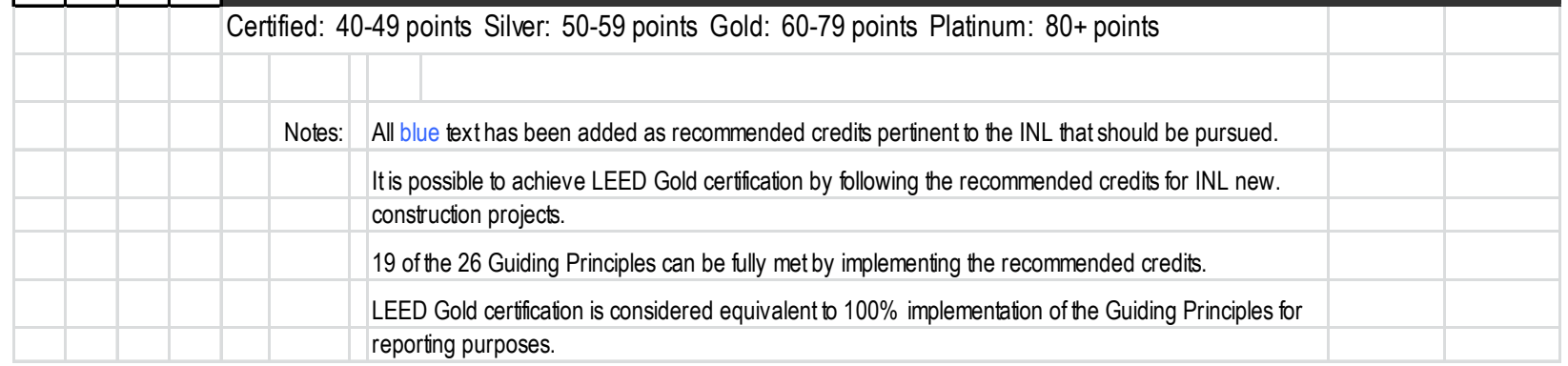




\section{BEST PRACTICES}

This section attempts to summarize a number of best practices for achieving success when designing, acquiring, and/or operating high performance buildings. It is not all encompassing, but it does feature a number of key areas, and contains recommendations from a number of sources.

- Utilize an integrated design process. An example of integrated design success is installing right-sized heating, ventilation, and air conditioning (HVAC) and lighting equipment to supplement passive comfort strategies; the resultant building will be much more cost effective over its life and may even have reduced capital costs for design and construction. It should be noted that this is also a requirement of the Guiding Principles. Refer to Attachment D, "Integrated Design Steps for Designers," for further discussion on what this means during each stage of the design and construction process. The following should be considered along with Attachment D:

- Require building simulation results for energy use at each design phase. This report should highlight load reductions for each design alternative and energy efficiency measure. During Conceptual Design these calculations will be valuable in relative terms rather than absolute terms.

- Require daylight simulation results (physical or digital models) for critical functional spaces as part of the Conceptual Design and Final Design Development packages.

- Use the design-build contract mechanism for high performance buildings, which is recommended by General Services Administration (GSA). Information on the "Two-Phase Design-Build Selection Procedures," Federal Acquisition Regulation (FAR) 36.3, can be found at: www.acquisition.gov/far/html/Subpart\%2036 3.html.

- Carefully select the design team based on their interview responses, references, and proven experience. Refer to Attachment C, "Hiring the Right Team," for further discussion.

- Calculate life-cycle costs to compare capital and projected O\&M costs and utilize these results to make informed decisions during the design process.

- Ensure certain technologies are always included despite the building type or project cost. These include efficient lighting (T-8s for general office areas, and CFLs and LEDs for task lighting and exit signs as appropriate), and occupancy sensors (general area lighting control system for larger office buildings), as well as set-back thermostats and economizer cycles for HVAC equipment. In addition, right-sized HVAC and lighting equipment should be installed to supplement passive comfort strategies. Full building control systems are the preferred method of controlling all building functions including lighting and HVAC and must be compatible with Engineering Specification 250100, "Instrumentation and Control Devices for HVAC."

- Carefully consider the following high performance building strategies for this geographical area of Southeastern Idaho, including daylighting with controls, night flush cooling, Cool Roofs with R30 insulation, high insulation levels (for winter), evaporative cooling, and careful entry way design (to combat the high winds in spring and fall). When including daylighting in the design, continue to check the implications of design decisions using physical or digital daylight testing to ensure success. This will also assist with achieving daylight credits in LEED if this is a goal; projects that only perform one daylight test at the beginning of design may not be able to achieve this credit.

- Do not use an energy model only for the purpose of achieving the LEED energy efficiency prerequisite and credits; use the model throughout the design process for making decisions on everything from building orientation to window types and window treatments.

- Require Building Information Modeling (BIM) as a standard. This technology supports integrated design and also offers potential cost savings. BIM will also benefit the continued operations and management of the facilities including Measurement and Verification (M\&V) and benchmarking. 
- As part of the M\&V required by the Guiding Principles, protocol should include a simple 1-page monthly report delivered to appropriate building personnel illustrating whole building Energy Use Index for the reporting period, and end-use break downs for HVAC, lighting, and plug loads when sub-metered, as a minimum.

- Consider utilizing a Post Occupancy Evaluation (staff survey) to be completed for a new building at the end of Year 1, Year 2, Year 5, and every 5 years to follow to evaluate thermal and visual comfort, as well as other indoor environmental quality attributes. These results should then be made available to the public to share lessons learned.

- During design, clearly state what type of lighting control is acceptable in a particular space type. Suggestions include requiring that daylight harvesting systems use dimming (or step dimming) ballasts in offices, classrooms, labs, and any other regularly occupied spaces, while step switching should only be allowed in spaces with less-critical visual tasks like medium and high bays, and corridors. 


\section{RESOURCES}

The process of creating a high performance building may be unfamiliar to some readers, but it has been experienced by many others. The best recommendation is to take advantage of those who are more experienced since this will help save both time and money. There are a number of resources available within INL including LEED Accredited Professionals and specific sustainability savvy organizations, as well as valuable resources available locally and nationally. The most useful resources are described in the following subsections.

\subsection{INL Resources}

\subsubsection{LEED Accredited Professionals}

A LEED Accredited Professional (AP) has demonstrated knowledge in green building design and the LEED rating system and passed an exam. The LEED AP credential process is now administered by the Green Building Certification Institute (GBCI) rather than the USGBC. The new process requires demonstrating one's eligibility through education or experience and taking a series of two exams: the LEED Green Associate, which covers general green building knowledge, and a specialty exam based on one of the LEED rating systems. Additional information is available on the GBCI Web site (www.gbci.org).

Building projects that include a LEED AP on the design team will earn a point towards certification. But more importantly, as discussed in the previous section on Financial Incentives, the LEED AP designation indicates depth of knowledge and familiarity with green building; therefore, the presence of LEED APs on the project team will benefit the project's budget, and contribute to the overall success towards meeting the DOE requirements.

INL has several LEED APs that can help with initial design specifications, work scope development, LEED credit evaluations, project review, and submittal documentation.

LEED APs at INL (as of April 2013):

- Active Primary Resources: Stephanie Austad, Matthew Hammond, and Ernest Fossum

- Inactive Secondary Resources: Cheryl O’Brien and Ross Allen.

\subsubsection{USGBC Membership}

INL is a USGBC member that allows for discounts when registering and certifying buildings, as well as purchasing training (workshops) and reference guides. Membership status also allows for access to additional material on the USGBC and GBCI Web sites.

INL's membership is under Battelle Corporate. Contact Stephanie Austad or Ernest Fossum for the Corporate Identification number.

\subsubsection{INL Organizations}

Many organizations at INL are available to assist with the areas covered in this document including leasing new office or laboratory space, designing a new building, or making recommendations for renovating an existing building. These organizations and the appropriate contact include:

- Applied Engineering: Kurt Ririe and Tracy Langenwalter

- Procurement Services: Michelle Wiest

- Project Management Office: Randall Bargelt

- Sustainable INL: Chris Ischay and Ernest Fossum. 


\subsection{General Resources}

Many resources are available within professional organizations as well as from other DOE laboratories that have successfully implemented green building projects on numerous facilities. The following resources, arranged alphabetically, are recommended for more information on designing, constructing, operating, and leasing high performance buildings:

ASHRAE, www.ashrae.org

Published various design documents including ASHRAE 90.1-2007, as well as guides for achieving a $30 \%$ reduction in energy use as compared to ASHRAE 90.1 (e.g., Advanced Energy Design Guide for Small Office Buildings). Most standards and guidelines are available for purchase as either hard copy or are downloadable; the Advanced Energy Design Guide series are available for free download.

DOE O 436.1, "Departmental Sustainability,"

https://www.directives.doe.gov/directives/0436.1-BOrder/view

Guiding Principles, "Guiding Principles for Sustainable New Construction and Major Renovations," and "Guiding Principles for Sustainable Existing Buildings."

www.wbdg.org/references/sustainable eo.php

Web site offers technical guidance, including Frequently Asked Questions (FAQs).

EO 13423, "Strengthening Federal Environmental, Energy, and Transportation Management," www.fedcenter.gov/programs/eo13423/

This Web site includes the EO text, implementing instructions, and additional information including guidance on particular areas. The EO fact sheet is also included as Attachment A in this document.

EO 13514, "Federal Leadership in Environmental, Energy, and Economic Performance,"

www.fedcenter.gov/programs/eo13514/

This Web site includes the EO text, overview, and crosswalk to EO 13423.

Federal Green Construction Guide for Specifiers, www.wbdg.org/design/greenspec.php

The Environmental Protection Agency (EPA) partnered with the Office of the Federal Environmental Executive (OFEE) and the Whole Building Design Guide to provide a comprehensive procurement guide for obtaining green building products and construction services within the federal government. The objective of the guide is to help federal agencies meet their project-specific environmental goals and mandates.

Green Building Certification Institute, GBCI Web site, www.gbci.org

This is the certifying body for LEED and the accreditation body for LEED APs; therefore, it is the location where a project can register and certify under the various LEED rating systems, and where to find information on LEED Professional Credentials, including becoming or locating a LEED AP.

Laboratories for the $21^{\text {st }}$ Century (Labs21), www.labs21century.gov

This resource is co-sponsored by the EPA and DOE and it is recommended when designing and/or constructing laboratory space. The Environmental Performance Criteria is a rating system based on LEED, and designed specifically for laboratory facilities.

LEED Reference Guides, available for purchase at www.usgbc.org

Every member of a project's design team is encouraged to have a copy of the applicable reference guide (available for different LEED rating systems). For each LEED credit, this essential resource details the standards, suggested strategies and technologies, and required documentation. (Reference guides are available for purchase as e-books or hard copies.) 
Sustainability Performance Office

The U.S. Department of Energy (DOE) Sustainability Performance Office (SPO) oversees departmental sustainability efforts required by Executive Order 13514, Executive Order 13423, and related federal laws and regulations. Learn more about SPO and its role within DOE:

http://www1.eere.energy.gov/sustainability/index.html.

University of Idaho Integrated Design Lab - Boise, www.idlboise.com

The Integrated Design Lab in Boise (IDL) is dedicated to the development of high performance energy efficient buildings in Idaho and Eastern Oregon. This is approached through research, education, and outreach efforts with students, owners, and professional design and construction teams to transform design and construction practice and keep pace with the milestones of the 2030 Challenge. Those who utilize the resources available through the IDL will design and construct buildings that are more comfortable for people, require less energy to maintain and operate, and enhance the health and productivity of building tenants. IDL offers daylighting and whole building energy design consultation and analysis.

USGBC Web site, www.usgbc.org

Green building resources including LEED checklists and other guidance for the various LEED rating systems, information, and sign-up for courses and workshops.

Whole Building Design Guide, www.wbdg.org

This resource from the National Institute of Building Sciences offers a great deal of information including guidance on the integrated design process. 


\section{SUMMARY}

This High Performance Building Strategy provides a guide for sustainable design at INL. Following the recommendations and requirements outlined will assist with obtaining the most sustainable, efficient, and healthy buildings possible for INL.

Including high performance and sustainable technical and functional requirements early in the facility development process will result in the maximum sustainability possible for the least amount of capital outlay. If performed correctly, the resultant building will be more life-cycle cost effective and may even reduce the initial capital cost for design and construction.

Providing healthy sustainable buildings is the key for INL's future in attracting the best and brightest minds to support INL's mission.

The recommended review cycle for this document is annually or as needed to stay current with the most recent executive and DOE orders, as well as the latest versions of the Guiding Principles, LEED rating systems, and the relevant INL programs. 


\section{REFERENCES}

ASHRAE, www.ashrae.org, web page accessed May 2013.

Baker, K., 2008, “Center for Advanced Energy Studies Cost Report for LEED Certification,” Prepared for the Idaho Division of Public Works and the Idaho Office of Energy Resources, June 2008.

Betterbricks, 2007, "Hiring the Right Team," October 2007, http://www.betterbricks.com/graphics/assets/documents/Hiring-the-team_Final.pdf, web page accessed May 2013.

Betterbricks, "Integrated Design Steps for Designers," www.betterbricks.com/graphics/assets/documents/BB Web integrated design.pdf, web page accessed May 2013.

Capehart, B. L., Turner, W. C., and Kennedy, W. J., 2006, Guide to Energy Management, The Fairmont Press, Fifth Edition, 2006.

DOE Guide 413.3-6, 2008, "High Performance Sustainable Building,” Department of Energy, July 2008.

DOE-ID, “INL Site Sustainability Plan,” DOE/ID-11383, February 13, 2013.

DOE Order 413.3B, "Program and Project Management for the Acquisition of Capital Assets," Department of Energy, July 2006.

DOE Order 436.1, “Departmental Sustainability,” May 2, 2011, https://www.directives.doe.gov/directives/0436.1-BOrder/view, web page accessed May 2013.

"DOE Strategic Sustainability Performance Plan"

DOE Sustainability Performance Office (SPO), http://www1.eere.energy.gov/sustainability/index.html, web page accessed May 2013.

Energy Independence and Security Act (EISA) of 2007.

Energy Policy Acts (EPAct) of 1992 and 2005

Engineering Specification 250100, "Instrumentation and Control Devices for HVAC"

Environmental Information Administration 2008

Executive Order 13423, "Strengthening Federal Environmental, Energy, and Transportation Management," January 2007, www.fedcenter.gov/programs/eo13423/, web page accessed May 2013.

Executive Order 13514, 2009, "Federal Leadership in Environmental, Energy, and Economic Performance," October 2009, www.fedcenter.gov/programs/eo13514/, web page accessed May 2013.

Federal Acquisition Regulation 36.3, "Two-Phase Design-Build Selection Procedures," www.acquisition.gov/far/html/Subpart\%2036_3html.

Green Building Certification Institute (GBCI), www.bgci.org, web page accessed May 2013.

Laboratories for the $21^{\text {st }}$ Century (Labs21), August 21, 2012, www.labs21 century.gov, Web page accessed May 2013.

ISWG, 2008, "Guiding Principles for Sustainable New Construction and Major Renovations," High Performance and Sustainable Buildings Guidance, Interagency Sustainability Working Group, December 2008.

Leadership in Energy and Environmental Design $\left(\right.$ LEED $\left.^{\circledR}\right)$ Green Building Rating System (LEED ${ }^{\circledR}$ 2009)

Kats, G., Alevantis, L., Berman, A., Mills, E., and Perlman, J., 2003, "The Costs and Financial Benefits of Green Buildings: A Report to California's Sustainable Buildings Task Force," October 2003. 
Matthiessen, L. F., and Morris, P., 2004, Costing Green: A Comprehensive Cost Database and Budgeting Methodology, Davis Langdon, July 2004.

Matthiessen, L. F., and Morris, P., 2007, Cost of Green Revisited: Reexamining the Feasibility and Cost Impact of Sustainable Design in the Light of Increased Market Adoption, Davis Langdon, July 2007.

National Energy Conservation Policy Act (NECPA), www1.eere.energy.gov/femp/regulations/necpa.html, web page accessed May 2013.

EPA, Pollution Prevention Act of 1990, www.epa.gov/p2/pubs/p2policy/act1990.htm, web page accessed May 2013.

Singh, A. and Sval, M. G., 2009, Life Cycle Cost Analysis of Occupant Well-being and Productivity in LEED Offices, Michigan State University.

University of Idaho Integrated Design Lab - Boise, www.idlboise.com, web page accessed May 2013.

U.S. Green Building Council (USGBC), LEED Reference Guides, www.usgbc.org, web page accessed May 2013.

Whole Building Design Guide (WBDG), "Guiding Principles for Sustainable New Construction and Major Renovations," www.wbdg.org/references/sustainable eo.php, web page accessed May 2013.

Whole Building Design Guide (WBDG), "Guiding Principles for Sustainable Existing Buildings," www.wbdg.org/references/sustainable eo.php, web page accessed May 2013.

Whole Building Design Guide (WBDG), "Federal Green Construction Guide for Specifiers," January 2010, www.wbdg.org/design/greenspec.php, web page accessed May 2013.

Whole Building Design Guide (WBDG), "Federal Leadership in High Performance and Sustainable Buildings Memorandum of Understanding” 2006. 


\section{ATTACHMENTS}

Attachment A, Executive Order 13423 Fact Sheet, "Strengthening Federal Environmental, Energy, and Transportation Management"

Attachment B, Guiding Principles

Attachment $\mathrm{C}$, Hiring the Right Team

Attachment D, Integrated Design Steps for Designers

Attachment E, Checklist for LEED for New Construction

Attachment F, Checklist for LEED for Existing Buildings: Operations \& Maintenance

Attachment G, Checklist for LEED for Core and Shell

Attachment H, Checklist for LEED for Commercial Interiors 


\section{Attachment A}

\section{Executive Order 13423 Fact Sheet}




\title{
Attachment A
}

\section{Executive Order 13423 Fact Sheet}

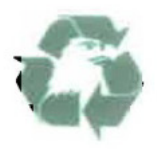

\author{
OFFICE OF THE FEDERAL ENVIRONMENTAL EXECUTIVE \\ 1200PENNSYLVANIA AVENUE, NW MAILCODE 1600S WASHINGTON, DC 20460 \\ (202) 5641297 WWW.OFEE.GOV TASK_FORCE@OFEE.GOV \\ PFomoting Sustainable ENVIRONMENTAL SteWARdship Throughout the FEDERAL GoVERnMENT
}

\section{FACT SHEET \\ Executive Order \\ Strengthening Federal Environmental, Energy, and Transportation Management}

The new Executive Order requires Federal agencies to lead by example in advancing the nation's energy security and environmental performance by achieving these goals:

- VEHICLES: Increase purchase of alternative fuel, hybrid, and plug-in hybrid vehicles when commercially available.

- PETROLEUM CONSERVATION: Reduce petroleum consumption in fleet vehicles by $2 \%$ annually through 2015 .

- ALTERNATIVE FUEL USE: Increase alternative fuel consumption at least $10 \%$ annually.

- $\quad$ ENERGY EFFICIENCY: Reduce energy intensity $30 \%$ by 2015 .

- GREENHOUSE GASES: Reduce greenhouse gas emissions through reduction of energy intensity by $3 \%$ annually or $30 \%$ by 2105 .

- RENEWABLE POWER: At least 50\% of current renewable energy purchases must come from new renewable sources (in service after January 1, 1999).

- BUILDING PERFORMANCE: Construct or renovate buildings in accordance with sustainability strategies, including resource conservation, reduction, and use; siting; and indoor environmental quality.

- WATER CONSERVATION: Reduce water consumption intensity by $2 \%$ annually through 2015 .

- PROCUREMENT: Expand purchases of environmentally-sound goods and services, including biobased products.

- POLLUTION PREVENTION: Reduce use of chemicals and toxic materials and purchase lower risk chemicals and toxic materials from top priority list.

- ELECTRONICS MANAGEMENT: Annually, 95\% of electronic products purchased must meet Electronic Product Environmental Assessment Tool standards where applicable; enable Energy Star@ features on $100 \%$ of computers and monitors; and reuse, donate, sell, or recycle $100 \%$ of electronic products using environmentally sound management practices.

- ENVIRONMENTAL MANAGEMENT SYSTEMS: By 2010, increase to at least 2,500 the number of Federal operations that implement environmental management systems, up from about 1,000 today.

The Executive Order consolidates and strengthens five executive orders and two memorandums of understanding and establishes new and updated goals, practices, and reporting requirements for environmental, energy, and transportation performance and accountability. 


\section{BACKGROUND ON EXECUTIVE ORDER GOALS AND COMPARISON WITH PAST AGENCY PERFORMANCE}

- Petroleum consumption: Updates expired goals of E.O. 13149. The Federal government had reduced petroleum consumption by $70 \%$ (119 to 36 trillion Btu) from 1985-2005.

- Energy efficiency: The new $30 \%$ energy efficiency goal seeks to achieve in 10 years the same level of improvement that Federal agencies achieved in the last 20 years and is $\mathbf{5 0 \%}$ more stringent than the goal in the Energy Policy Act of 2005. The Federal government improved energy efficiency $29.6 \%$ between 1985 and 2005.

- GHG emissions: Will be realized through other E.O. goals that will exceed the prior 30\% goal (E.O. 13123). The Federal government reduced GHG emissions by $22.1 \%$ ( 14.9 to $11.6 \mathrm{MTCE})$ between 1990 and 2005, towards the E.O. 13123 goal of $30 \%$ by 2010 .

- Renewable power: The Energy Policy Act of 2005 sets a renewable energy goal but does not require that any percentage come from new sources. The prior E.O. 13123 set a goal of $2.5 \%$ for renewable power purchases. The Federal government exceeded that goal with purchases totaling $6.9 \%$ during the period 2000-2005.

- Water consumption: Prior orders did not include such a goal. However, good environmental practices reduced water consumption by $19.6 \%$ from $2000-2005$.

- Procurement: The new E.O. and guidance require agencies to integrate four existing disparate purchasing requirements into an integrated Federal purchasing effort that applies to all types of acquisitions of goods and services. Federal purchasing of energy efficient, recycled content, biobased, and environmentally preferable products will increase as a result. The E.O. also continues the requirement that agencies purchase office paper containing 30 percent postconsumer fiber.

- Buildings: The order makes mandatory the elements of the High Performance Buildings MOU signed by 19 agencies in January 2006. From 1985 to 2005, on average, building energy use decreased $12.9 \%$, or $16.3 \%$ energy intensity (Btu/gross sq. $\mathrm{ft}$ ).

- $\quad$ Electronics: The order makes mandatory the elements of the 2004 Federal Electronics Stewardship MOU signed by 12 agencies and the Executive Office of the President. The Federal government spends approximately $\$ 60$ billion annually on IT-related purchases.

- Toxics: The order requires agencies to reduce their purchase and use of hazardous and toxic chemicals. 
Attachment B

\section{Guiding Principles}




\section{Attachment B}

\section{Guiding Principles}

\section{GUIDING PRINCIPLES FOR SUSTAINABLE NEW CONSTRUCTION AND MAJOR RENOVATIONS}

\section{Employ Integrated Design Principles}

Integrated Design. Use a collaborative, integrated planning and design process that

- Initiates and maintains an integrated project team as described on the Whole Building Design Guide < $<$ ttp://www.wbdg.org/design/engage_process.php $>$ in all stages of a project's planning and delivery

- Integrates the use of OMB's A-11, Section 7, Exhibit 300: Capital Asset Plan and Business Case Summary

- Establishes performance goals for siting, energy, water, materials, and indoor environmental quality along with other comprehensive design goals and ensures incorporation of these goals throughout the design and lifecycle of the building

- Considers all stages of the building's lifecycle, including deconstruction.

Commissioning. Employ commissioning practices tailored to the size and complexity of the building and its system components in order to verify performance of building components and systems and help ensure that design requirements are met. This should include an experienced commissioning provider, inclusion of commissioning requirements in construction documents, a commissioning plan, verification of the installation and performance of systems to be commissioned, and a commissioning report.

\section{Optimize Energy Performance}

Energy Efficiency. Establish a whole building performance target that takes into account the intended use, occupancy, operations, plug loads, other energy demands, and design to earn the ENERGY STAR ${ }^{\circledR}$ targets for new construction and major renovation where applicable. For new construction, reduce the energy use by 30 percent compared to the baseline building performance rating per the American National Standards Institute (ANSI)/ American Society of Heating, Refrigerating and Air-Conditioning Engineers, Inc., (ASHRAE)/Illuminating Engineering Society of North America (IESNA) Standard 90.1-2007, Energy Standard for Buildings Except Low-Rise Residential. For major renovations, reduce the energy use by 20 percent below prerenovations 2003 baseline. Laboratory spaces may use the Labs21 Laboratory Modeling Guidelines. Use ENERGY STAR ${ }^{\circledR}$ and FEMP-designated Energy Efficient Products, where available.

On-Site Renewable Energy. Per the Energy Independence and Security Act (EISA) Section 523, meet at least $30 \%$ of the hot water demand through the installation of solar hot water heaters, when lifecycle cost effective. 
Per Executive Order 13423, implement renewable energy generation projects on agency property for agency use, when lifecycle cost effective.

Measurement and Verification. Per the Energy Policy Act of 2005 (EPAct) Section 103, install building level electricity meters in new major construction and renovation projects to track and continuously optimize performance. Per EISA Section 434, include equivalent meters for natural gas and steam, where natural gas and steam are used.

Benchmarking. Compare actual performance data from the first year of operation with the energy design target, preferably by using ENERGY STAR ${ }^{\circledR}$ Portfolio Manager for building and space types covered by ENERGY STAR ${ }^{\circledR}$. Verify that the building performance meets or exceeds the design target, or that actual energy use is within $10 \%$ of the design energy budget for all other building types. For other building and space types, use an equivalent benchmarking tool such as the Labs21 benchmarking tool for laboratory buildings.

\section{Protect and Conserve Water}

Indoor Water. Employ strategies that in aggregate use a minimum of 20 percent less potable water than the indoor water use baseline calculated for the building, after meeting the EPAct 1992, Uniform Plumbing Codes 2006, and the International Plumbing Codes 2006 fixture performance requirements. The installation of water meters is encouraged to allow for the management of water use during occupancy. The use of harvested rainwater, treated wastewater, and air conditioner condensate should also be considered and used where feasible for nonpotable use and potable use where allowed.

Outdoor Water. Use water efficient landscape and irrigation strategies, such as water reuse, recycling, and the use of harvested rainwater, to reduce outdoor potable water consumption by a minimum of 50 percent over that consumed by conventional means (plant species and plant densities). The installation of water meters for locations with significant outdoor water use is encouraged.

Employ design and construction strategies that reduce storm water runoff and discharges of polluted water offsite. Per EISA Section 438, to the maximum extent technically feasible, maintain or restore the predevelopment hydrology of the site with regard to temperature, rate, volume, and duration of flow using site planning, design, construction, and maintenance strategies.

Process Water. Per the Energy Policy Act of 2005 Section 109, when potable water is used to improve a building's energy efficiency, deploy lifecycle cost effective water conservation measures.

Water-Efficient Products. Specify EPA's WaterSense-labeled products or other water conserving products, where available. Choose irrigation contractors who are certified through a WaterSense labeled program. 


\section{Enhance Indoor Environmental Quality}

Ventilation and Thermal Comfort. Meet ASHRAE Standard 55-2004, Thermal Environmental Conditions for Human Occupancy, including continuous humidity control within established ranges per climate zone, and ASHRAE Standard 62.1-2007, Ventilation for Acceptable Indoor Air Quality.

Moisture Control. Establish and implement a moisture control strategy for controlling moisture flows and condensation to prevent building damage, minimize mold contamination, and reduce health risks related to moisture.

Daylighting. Achieve a minimum daylight factor of 2 percent (excluding all direct sunlight penetration) in 75 percent of all space occupied for critical visual tasks. Provide automatic dimming controls or accessible manual lighting controls, and appropriate glare control.

Low-Emitting Materials. Specify materials and products with low pollutant emissions, including composite wood products, adhesives, sealants, interior paints and finishes, carpet systems, and furnishings.

Protect Indoor Air Quality during Construction. Follow the recommended approach of the Sheet Metal and Air Conditioning Contractor's National Association Indoor Air Quality Guidelines for Occupied Buildings under Construction, 2007. After construction and prior to occupancy, conduct a minimum 72-hour flush-out with maximum outdoor air consistent with achieving relative humidity no greater than 60 percent. After occupancy, continue flush-out as necessary to minimize exposure to contaminants from new building materials.

Environmental Tobacco Smoke Control. Implement a policy and post signage indicating that smoking is prohibited within the building and within 25 feet of all building entrances, operable windows, and building ventilation intakes during building occupancy. 


\section{Reduce Environmental Impact of Materials}

Recycled Content. Per Section 6002 of the Resource Conservation and Recovery Act (RCRA), for EPA-designated products, specify products meeting or exceeding EPA's recycled content recommendations. For other products, specify materials with recycled content when practicable. If EPA-designated products meet performance requirements and are available at a reasonable cost, a preference for purchasing them shall be included in all solicitations relevant to construction, operation, maintenance of or use in the building. EPA's recycled content product designations and recycled content recommendations are available on EPA's Comprehensive Procurement Guideline web site at <www.epa.gov/cpg $>$.

Biobased Content. Per Section 9002 of the Farm Security and Rural Investment Act (FSRIA), for USDA-designated products, specify products with the highest content level per USDA's biobased content recommendations. For other products, specify biobased products made from rapidly renewable resources and certified sustainable wood products. If these designated products meet performance requirements and are available at a reasonable cost, a preference for purchasing them shall be included in all solicitations relevant to construction, operation, maintenance of or use in the building. USDA's biobased product designations and biobased content recommendations are available on USDA's BioPreferred web site at <www.usda.gov/biopreferred $>$.

Environmentally Preferable Products. Use products that have a lesser or reduced effect on human health and the environment over their lifecycle when compared with competing products or services that serve the same purpose. A number of standards and ecolabels are available in the marketplace to assist specifiers in making environmentally preferable decisions. For recommendations, consult the Federal Green Construction Guide for Specifiers at $<\underline{w w w}$.wbdg.org/design/greenspec.php $>$.

Waste and Materials Management. Incorporate adequate space, equipment, and transport accommodations for recycling in the building design. During a project's planning stage, identify local recycling and salvage operations that could process siterelated construction and demolition materials. During construction, recycle or salvage at least 50 percent of the non-hazardous construction, demolition and land clearing materials, excluding soil, where markets or onsite recycling opportunities exist. Provide salvage, reuse and recycling services for waste generated from major renovations, where markets or onsite recycling opportunities exist.

Ozone Depleting Compounds. Eliminate the use of ozone depleting compounds during and after construction where alternative environmentally preferable products are available, consistent with either the Montreal Protocol and Title VI of the Clean Air Act Amendments of 1990, or equivalent overall air quality benefits that take into account lifecycle impacts. 


\section{GUIDING PRINCIPLES FOR SUSTAINABLE EXISTING BUILDINGS}

\section{Employ Integrated Assessment, Operation, and Management Principles}

Integrated Assessment, Operation, and Management. Use an integrated team to develop and implement policy regarding sustainable operations and maintenance.

- Incorporate sustainable operations and maintenance practices within the appropriate Environmental Management System (EMS)

- Assess existing condition and operational procedures of the building and major building systems and identify areas for improvement

- Establish operational performance goals for energy, water, material use and recycling, and indoor environmental quality, and ensure incorporation of these goals throughout the remaining lifecycle of the building

- Incorporate a building management plan to ensure that operating decisions and tenant education are carried out with regard to integrated, sustainable building operations and maintenance

- Augment building operations and maintenance as needed using occupant feedback on work space satisfaction.

Commissioning. Employ recommissioning, tailored to the size and complexity of the building and its system components, in order to optimize and verify performance of fundamental building systems. Commissioning must be performed by an experienced commissioning provider. When building commissioning has been performed, the commissioning report, summary of actions taken, and schedule for recommissioning must be documented. In addition, meet the requirements of EISA 2007, Section 432 and associated FEMP guidance.

Building recommissioning must have been performed within four years prior to reporting a building as meeting the Guiding Principles.

\section{Optimize Energy Performance}

Energy Efficiency. Three options can be used to measure energy efficiency performance:

- Option 1: Receive an ENERGY STAR ${ }^{\circledR}$ rating of 75 or higher or an equivalent Labs21 Benchmarking Tool score for laboratory buildings,

- Option 2: Reduce measured building energy use by $20 \%$ compared to building energy use in 2003 or a year thereafter with quality energy use data, or 
- Option 3: Reduce energy use by 20\% compared to the ASHRAE 90.1-2007 baseline building design if design information is available.

Use ENERGY STAR ${ }^{\circledR}$ and FEMP-designated Energy Efficient Products, where available.

On-Site Renewable Energy. Per Executive Order 13423, implement renewable energy generation projects on agency property for agency use, when lifecycle cost effective.

Measurement and Verification. Per the Energy Policy Act of 2005 (EPAct2005) Section 103, install building level electricity meters to track and continuously optimize performance. Per the Energy Independence and Security Act (EISA) 2007, the utility meters must also include natural gas and steam, where natural gas and steam are used.

Benchmarking. Compare annual performance data with previous years' performance data, preferably by entering annual performance data into the ENERGY STAR ${ }^{\circledR}$ Portfolio Manager. For building and space types not available in ENERGY STAR ${ }^{\circledR}$, use an equivalent benchmarking tool such as the Labs21 benchmarking tool for laboratory buildings.

\section{Protect and Conserve Water}

Indoor Water. Two options can be used to measure indoor potable water use performance:

- Option 1: Reduce potable water use by $20 \%$ compared to a water baseline calculated for the building. The water baseline, for buildings with plumbing fixtures installed in 1994 or later, is $120 \%$ of the Uniform Plumbing Codes 2006 or the International Plumbing Codes 2006 fixture performance requirements. The water baseline for plumbing fixtures older than 1994 is $160 \%$ of the Uniform Plumbing Codes 2006 or the International Plumbing Codes 2006 fixture performance requirements, or

- Option 2: Reduce building measured potable water use by $20 \%$ compared to building water use in 2003 or a year thereafter with quality water data.

Outdoor Water. Three options can be used to measure outdoor potable water use performance:

- Option 1: Reduce potable irrigation water use by $50 \%$ compared to conventional methods, or

- Option 2: Reduce building related potable irrigation water use by $50 \%$ compared to measured irrigation water use in 2003 or a year thereafter with quality water data, or

- Option 3: Use no potable irrigation water.

Measurement of Water Use. The installation of water meters for building sites with significant indoor and outdoor water use is encouraged. If only one meter is installed, 
reduce potable water use (indoor and outdoor combined) by at least $20 \%$ compared to building water use in 2003 or a year thereafter with quality water data.

Employ strategies that reduce storm water runoff and discharges of polluted water offsite. Per EISA Section 438, where redevelopment affects site hydrology, use site planning, design, construction, and maintenance strategies to maintain hydrologic conditions during development, or to restore hydrologic conditions following development, to the maximum extent that is technically feasible.

Process Water. Per EPAct 2005 Section 109, when potable water is used to improve a building's energy efficiency, deploy lifecycle cost effective water conservation measures.

Water-Efficient Products. Where available, use EPA's WaterSense-labeled products or other water conserving products. Choose irrigation contractors who are certified through a WaterSense-labeled program.

\section{Enhance Indoor Environmental Quality}

Ventilation and Thermal Comfort. Meet ASHRAE Standard 55-2004 Thermal Environmental Conditions for Human Occupancy and ASHRAE Standard 62.1-2007: Ventilation for Acceptable Indoor Air Quality.

Moisture Control. Provide policy and illustrate the use of an appropriate moisture control strategy to prevent building damage, minimize mold contamination, and reduce health risks related to moisture. For façade renovations, Dew Point analysis and a plan for cleanup or infiltration of moisture into building materials are required.

Daylighting and Lighting Controls. Automated lighting controls (occupancy/vacancy sensors with manual-off capability) are provided for appropriate spaces including restrooms, conference and meeting rooms, employee lunch and break rooms, training classrooms, and offices. Two options can be used to meet additional daylighting and lighting controls performance expectations:

- Option 1: Achieve a minimum daylight factor of 2 percent (excluding all direct sunlight penetration) in 50 percent of all space occupied for critical visual tasks, or

- Option 2: Provide occupant controlled lighting, allowing adjustments to suit individual task needs, for $50 \%$ of regularly occupied spaces.

Low-Emitting Materials. Use low emitting materials for building modifications, maintenance, and cleaning. In particular, specify the following materials and products to have low pollutant emissions: composite wood products, adhesives, sealants, interior paints and finishes, solvents, carpet systems, janitorial supplies, and furnishings. 
Integrated Pest Management. Use integrated pest management techniques as appropriate to minimize pesticide usage. Use EPA-registered pesticides only when needed.

Environmental Tobacco Smoke Control. Prohibit smoking within the building and within 25 feet of all building entrances, operable windows, and building ventilation intakes.

\section{Reduce Environmental Impact of Materials}

Recycled Content. Per section 6002 of RCRA, for EPA-designated products, use products meeting or exceeding EPA's recycled content recommendations for building modifications, maintenance, and cleaning. For other products, use materials with recycled content such that the sum of postconsumer recycled content plus one-half of the preconsumer content constitutes at least $10 \%$ (based on cost or weight) of the total value of the materials in the project. If EPA-designated products meet performance requirements and are available at a reasonable cost, a preference for purchasing them shall be included in all solicitations relevant to construction, operation, maintenance of or use in the building. EPA's recycled content product designations and recycled content recommendations are available on EPA's Comprehensive Procurement

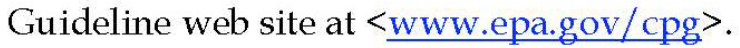

Biobased Content. Per section 9002 of FSRIA, for USDA-designated products, use products with the highest content level per USDA's biobased content recommendations. For other products, use biobased products made from rapidly renewable resources and certified sustainable wood products. If these designated products meet performance requirements and are available at a reasonable cost, a preference for purchasing them should be included in all solicitations relevant to construction, operation, maintenance of or use in the building. USDA's biobased product designations and biobased content recommendations are available on USDA's BioPreferred web site at $<$ www.usda.gov/biopreferred $>$.

Environmentally Preferable Products. Use products that have a lesser or reduced effect on human health and the environment over their lifecycle when compared with competing products or services that serve the same purpose. A number of standards and ecolabels are available in the marketplace to assist specifiers in making environmentally preferable decisions. For recommendations, consult the Federal Green Construction Guide for Specifiers at < $\underline{w w w . w b d g . o r g / d e s i g n / g r e e n s p e c . p h p}>$.

Waste and Materials Management. Provide reuse and recycling services for building occupants, where markets or on-site recycling exist. Provide salvage, reuse and recycling services for waste generated from building operations, maintenance, repair and minor renovations, and discarded furnishings, equipment and property. This could include such things as beverage containers and paper from building occupants, 
batteries, toner cartridges, outdated computers from an equipment update, and construction materials from a minor renovation.

Ozone Depleting Compounds. Eliminate the use of ozone depleting compounds where alternative environmentally preferable products are available, consistent with either the Montreal Protocol and Title VI of the Clean Air Act Amendments of 1990, or equivalent overall air quality benefits that take into account lifecycle impacts. 


\section{Attachment C}

\section{Hiring the Right Team}




\section{Attachment C}

\section{Hiring the Right Team}

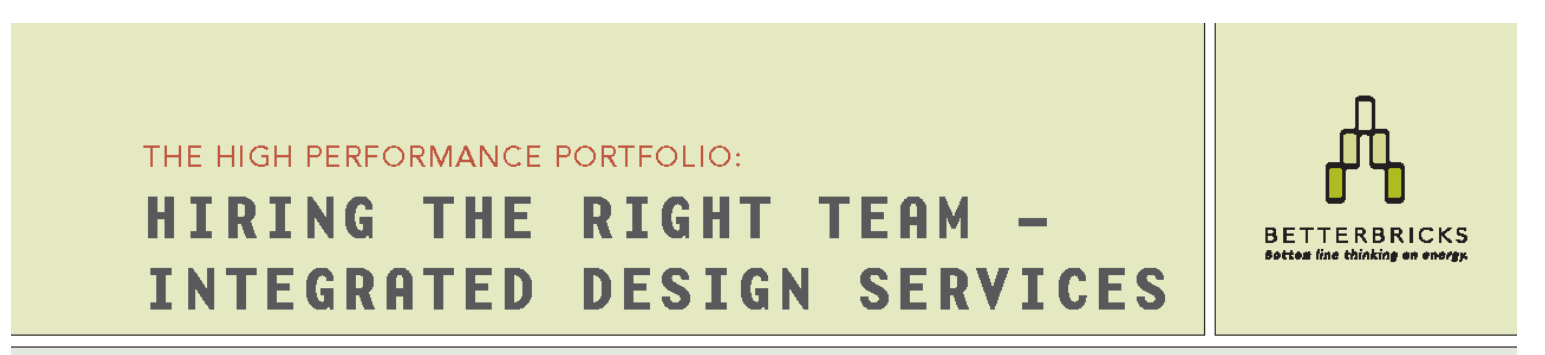

Designing and creating high performance buildings is a maturing discipline. Many practices and strategies differ significantly from traditional development, requiring new skills and technical expertise to deliver projects at their optimum level of energy performance. Further, development of high performance buildings require a fundamental shift in management style - an innovative, collaborative, multi-disciplinary approach - which can prove difficult to master. Owners and developers seeking architectural, engineering, and construction services should re-examine the process for securing qualified firms, and focus on finding those that either have experience in integrated design or can quickly come up to speed.

IN DEPTH:

The practice of integrated design (and high performance buildings as a whole) is rapidly evolving. Many architects and designers are still developing and refining their skills in these areas. Ideally, seek an experienced design team that has had success managing an integrated design process.

However, it may prove difficult to locate the exact qualifications you need. If that's the case, consider ways to allow for "on-the-job training" among team members. Even with an experienced group, allocate time and resources for the team to research innovative strategies and techniques - a consideration unique to integrated design services, given their cutting-edge nature. This doesn't necessarily translate to additional time or cost. Firms eager to boost their expertise and professional reputation might be willing to adjust their negotiated fee or the timing of that fee in order to build their knowledge base.

When evaluating a design team, consider their familiarity with the following concepts and techniques:

- Employing a holistic approach to building systems, materials, design, and operations to maximize efficiency, occupant comfort, and cost-effectiveness

- Conducting energy modeling

- Minimizing building energy loads

- Implementing efficient lighting strategies, integrated with daylighting

- Employing natural ventilation

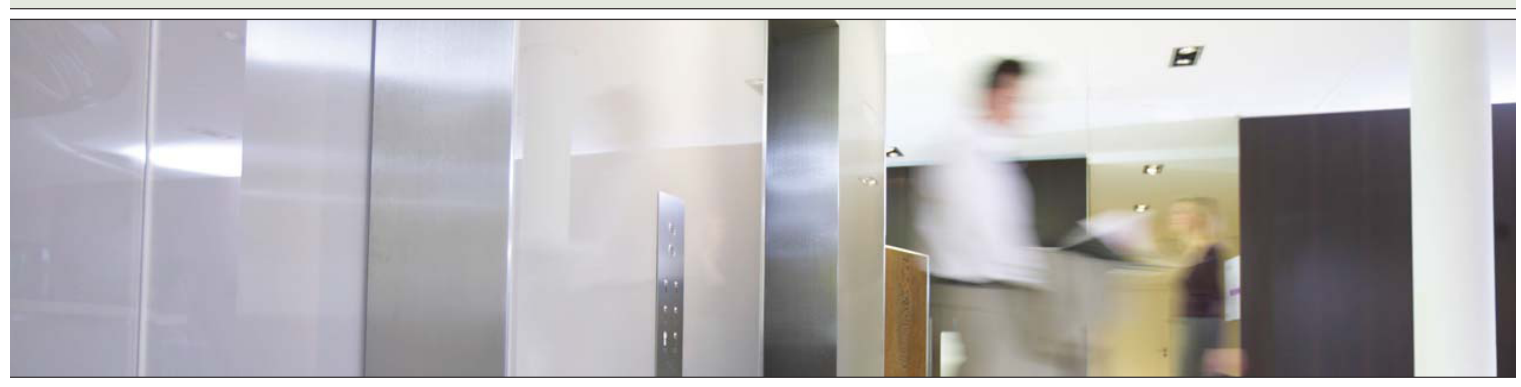


- Assessing alternative mechanical system strategies

- Training building staff on enhanced operations \& maintenance procedures

- Assessing life-cycle costs of building systems

- Using building information models (BIM) as a tool for team integration

- Working collabor atively early in the design process with multiple stakeholders

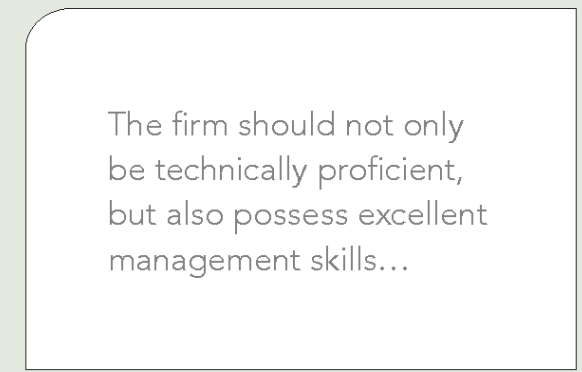

The firm should not only be technically proficient, but also possess excellent management skills, which are essential for the highly collaborative integrated design process. Gauge the firm's management style, and see if they have the flexibility to break away from the silos of traditional design. Team members must be able to effectively communicate design details and solicit input from an expanded circle of professionals, such as owners,

\section{AIA RESOURCES}

The American Institute of Architects (AIA) has recognized that integrated design represents a shift in the traditional design process, and is currently preparing reference materials for use by the development community to promote the adoption of this practice. The AlA Integrated Project Delivery: A Guide is expected to be released in November of 2007. Also, AlA Contract Documents for Integrated Project Delivery - contract templates for use by design teams - will be released in conjunction with the AlA national convention in the spring of 2008. developers, architects, engineers, contractors, proposed occupants, commissioning agents, O\&M staff, energy consultants, mixed-use experts, and others. In particular, look for personnel that are fluent in managerial issues, cross-functional teams, and the other concepts associated with integrated design.

The selected design team must be familiar with and supportive of value the commissioning agent brings to the process. Integrated design incorporates commissioning from the earliest stages, and the design team must be prepared to work with third-party commissioning agents at multiple touch-points.

Check references carefully, and broaden the scope of your interviews to explore integrated design qualifications. Ask questions of potential team members. For example, find out whether the firm utilizes an integrated approach only in the early phases of design or throughout the entire process. Also, be sure to understand what their definition of integrated design really is - it might not necessarily meet your criteria. 


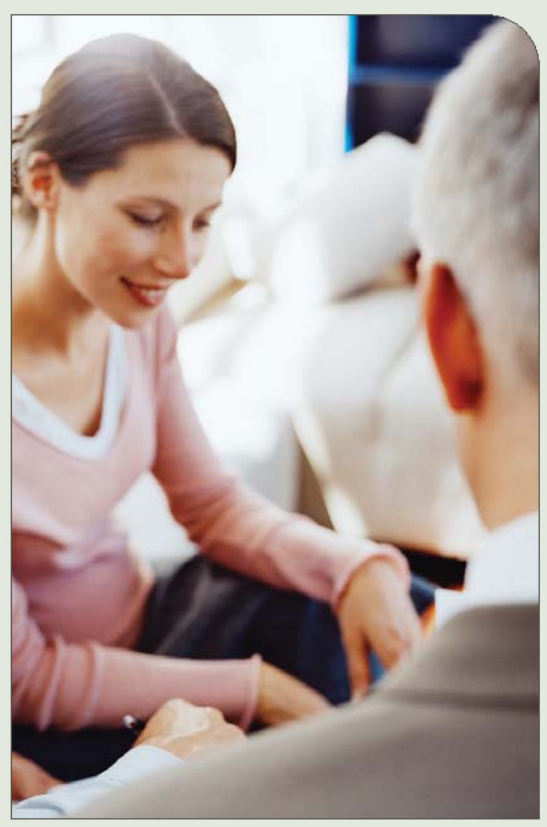

Even if you've found a team with the necessary skills, don't assume the architects, designers, and engineers know everything. If necessary, bring in additional expertise and consultants to supplement the team. For example, "green building" or sustainability consultants can play an important role in the development of high-performance buildings, often running charrettes or guiding developers through green building certification programs. Specialists in energy, site sustainability, lighting, green materials, or new technologies might also be required.

Some architectural firms have these experts on staff; others bring on external consultants for each project. Find out whether potential design teams plan to bring in special consultants, and if not, include provisions for this in the contract. Or you might consider hiring sustainability consultants first, and then working with them to search for architects, engineers, contractors, and other experts.

As an additional way of maximizing expertise, encourage a crossfunctional mindset. Though it's important to involve specialists in all areas, the team should foster a climate of contribution. For example, the water expert can come up with HVAC solutions; the HVAC expert can come up with building envelope solutions. Seek and welcome input from a wide array of views, as opposed to a traditional hand-off process from architect to engineer to contractor.

When you're ready to secure the firm, pay attention to several contractual issues unique to integrated design:

- Integrated design is more time-intensive early in the process compared to a conventional project, with less time required during later design and construction stages. While design teams traditionally receive a percentage of the total fee during each phase of the project, the fees specified in contracts for integrated design services should reflect the timing of involvement and a greater effort in the early design stages.

- Typically, a mechanical engineer's fee is a percentage of the total mechanical equipment installed. This set-up makes less sense for high performance buildings, which aim for reduced loads and minimal equipment size. Establish a fee structure that Establish a fee structure rewards efficiency, not excess.

that rewards efficiency, not excess. 
- Ensure that the architects have their team established early on, including all sub-consultants, engineers, and other experts. To gain confidence that the team has all the necessary skills and to ensure that all members can contribute in the pre-design phase, you'll need to know who they are before you sign the contract.

- Build energy performance goals into contracts for all sub-contractors and consultants, in addition to the architectural firm's contract.

- Finally, remember that integrated design can result in a lower overall project cost. Potentially higher up-front costs will be recovered later during construction.

\section{THE BOTTOM LINE :}

- Seek an experienced design team with a proven track record, but acknowledge that some on-thejob training will be required

- Evaluate teams' familiarity with innovative integrated design methodologies, energy modeling, life-cycle cost analysis, and building operator training

- The design team should possess the fundamental management skills necessary to lead in a collaborative team environment
- Bring in additional expertise and consultants to supplement the team as necessary, and encourage a cross-functional mindset to maximize expertise

- Fully integrate the commissioning agent's role throughout the integrated design process.

- Contracts may need to be re-examined to set proper expectations about project milestones, payment schedules, and performance criteria

\section{LEARN MORE:}

The High Performance Portfolio Framework www.betterbricks.com/office/framework

Sample RFP for Integrated Design Services www. betterbricks. com/office/briefs
BetterBricks Design \& Construction Resources www, bet terbricks, com/design

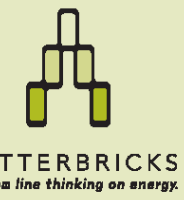

BETTERBRICKS 


\section{Attachment D}

\section{Integrated Design Steps for Designers}




\section{Attachment D}

\section{Integrated Design Steps for Designers}

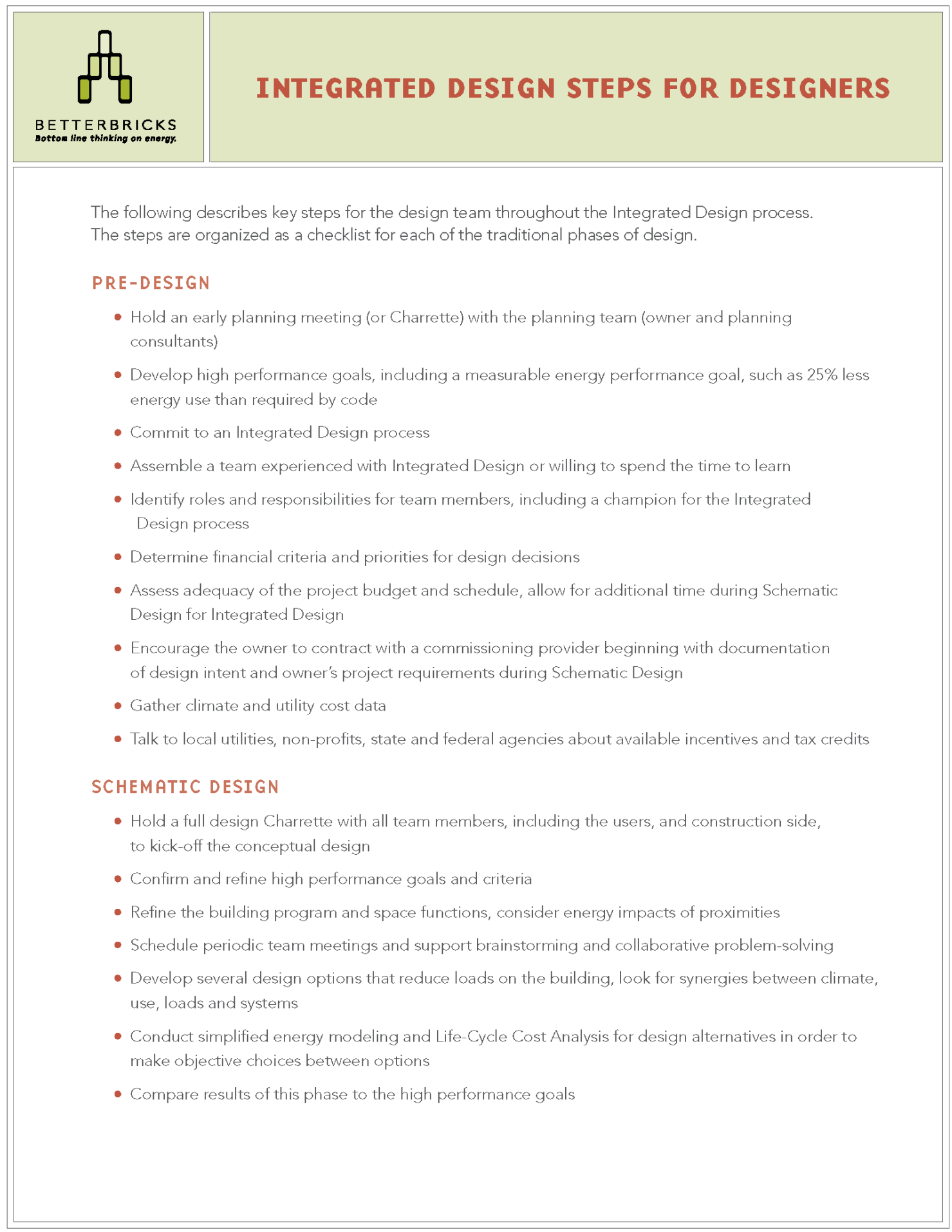




\section{DESIGN DEVELOPMENT}

- Discuss potential building systems and identify high efficiency options

- Conduct whole-building energy modeling to confirm the design meets the high performance goals, and to confirm eligibility for rating systems, incentives and tax credits

- Verify, with the owner, that the design documents at this stage contain the strategies to meet the performance goals

- Ask the whole team to help assess the preliminary cost model

- During value engineering, vigorously defend the value of high performance features as being integral to the whole building design and function

\section{CONSTRUCTION DOCUMENTS}

- Invite the commissioning provider, and maintenance and operations staff to conduct a document review of building systems

- Hold frequent coordination meetings to keep communication flowing among team members

- Update the cost model and schedule with input from the team

- Request documentation from the team that indicates how the project compares to the high performance goals set in Pre-Design

- Verify that the construction documents contain the strategies to meet the performance goals (consider asking the commissioning provider and contractor, to conduct this review)

\section{CONSTRUCTION}

- Conduct a construction kick-off meeting with the contractors and subcontractors to secure their commitment to the high performance goals before construction starts

- Review submittals and substitution requests for impact on the performance goals

- At the end of construction and prior to occupancy, allow time for the commissioning provider to complete functional testing and O\&M training

- Review the commissioning report with the owner and have the contractor address any recommended repairs or alterations

\section{OCCUPANCY}

- Assist the owner and facility team to establish an ongoing energy management program, including training and periodic re-commissioning

- After the warranty period shakedown, verify that high performance goals were met, assess occupant satisfaction, and share feedback with the whole team 


\section{Attachment E}

\section{Checklist for LEED ${ }^{\circledR}$ for New Construction}




\section{Attachment E}

\section{Checklist for LEED ${ }^{\circledast}$ for New Construction}

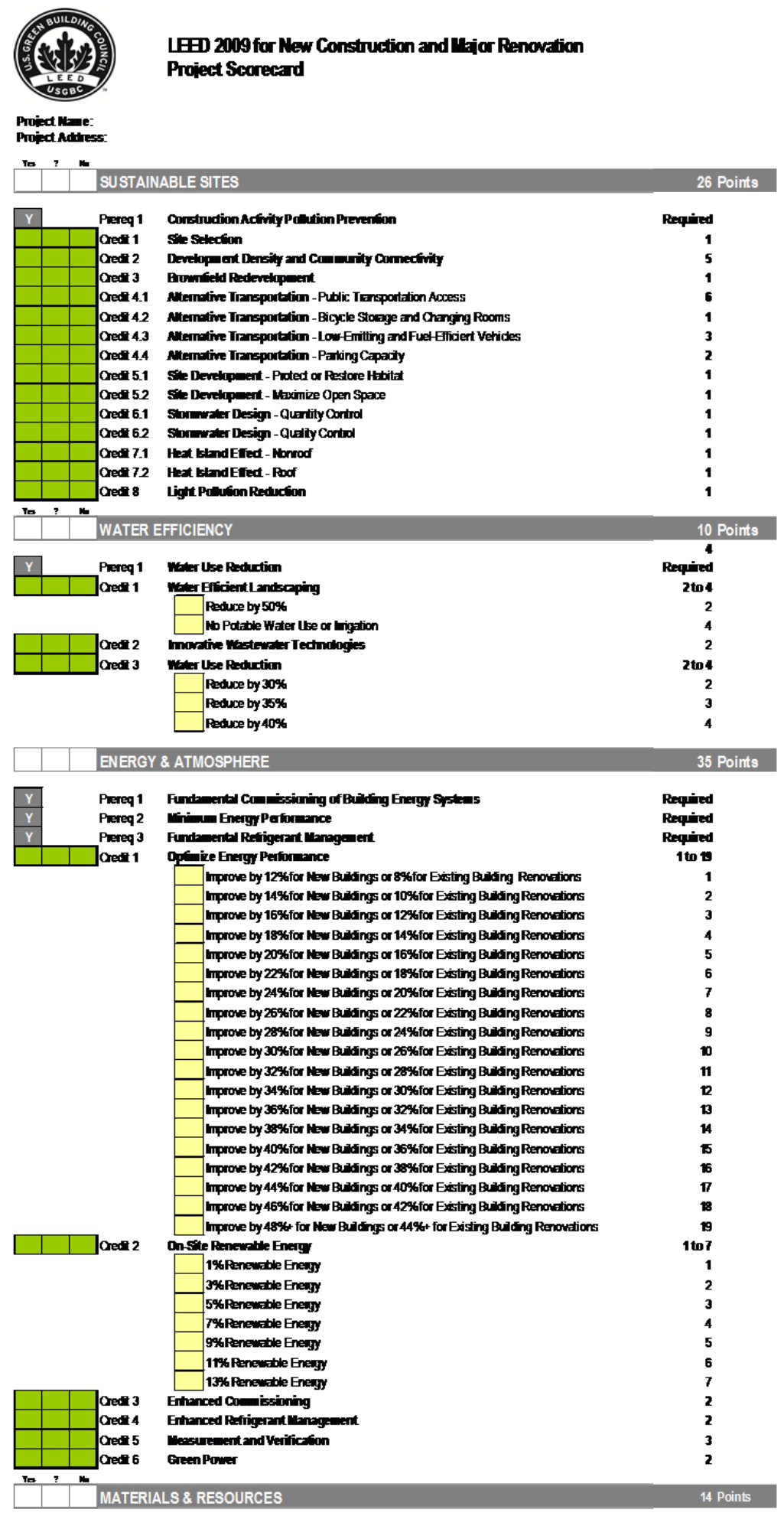



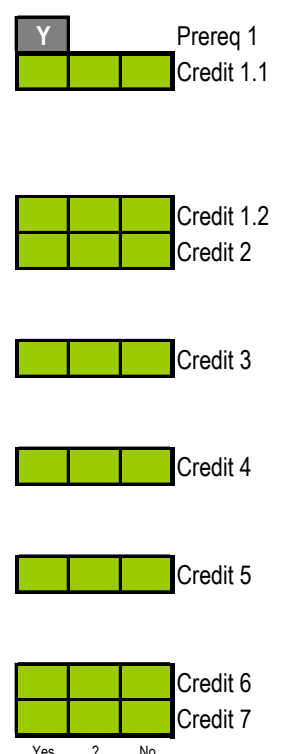

Credit 7

\section{INDOOR ENVIRONMENTAL QUALITY}

Reuse 55\%

Reuse $75 \%$

Reuse 95\%

$50 \%$ Recycled or Salvaged

$75 \%$ Recycled or Salvaged

Materials Reuse

Reuse 5\%

Reuse 10\%

Recycled Content

$10 \%$ of Content

$20 \%$ of Content

Regional Materials

$10 \%$ of Materials

$20 \%$ of Materials

Rapidly Renewable Materials

Certified Wood
Building Reuse - Maintain Existing Walls, Floors and Roof

Building Reuse - Maintain Interior Nonstructural Elements

Construction Waste Management
Required

1 to 3

Required
1 to 3
1
2
3
1
1 to 2
1
2
1 to 2
1
2
1 to 2
1
2
1 to 2
1
2
1
1

15 Points

Prereq 1 Minimum Indoor Air Quality Performance Required

Prereq 2 Environmental Tobacco Smoke (ETS) Control Required

Credit 1 Outdoor Air Delivery Monitoring 1

Credit 2 Increased Ventilation $\quad 1$

Credit 3.1 Construction Indoor Air Quality Management Plan - During Construction 1

Credit 3.2 Construction Indoor Air Quality Management Plan - Before Occupancy 1

Credit 4.1 Low-Emitting Materials - Adhesives and Sealants 1

Credit 4.2 Low-Emitting Materials - Paints and Coatings 1

Credit 4.3 Low-Emitting Materials - Flooring Systems 1

Credit 4.4 Low-Emitting Materials - Composite Wood and Agrifiber Products 1

Credit $5 \quad$ Indoor Chemical and Pollutant Source Control 1

Credit 6.1 Controllability of Systems - Lighting 1

Credit 6.2 Controllability of Systems - Thermal Comfort 1

Credit 7.1 Thermal Comfort - Design 1

Credit 7.2 Thermal Comfort - Verification 1

Credit 8.1 Daylight and Views - Daylight 1

Credit 8.2 Daylight and Views - Views 1

INNOVATION IN DESIGN 6 Points

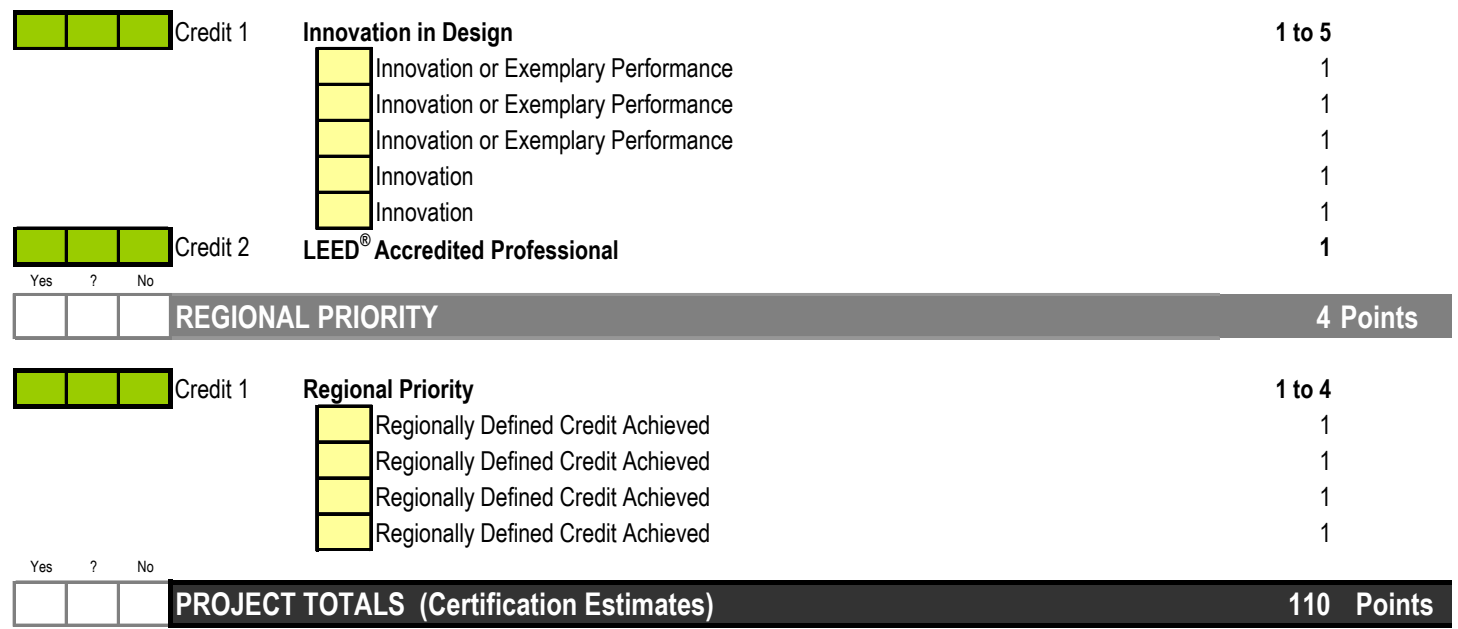

Certified: $40-49$ points Silver: $50-59$ points Gold: $60-79$ points Platinum: $80+$ points 
Attachment F

\section{Checklist for LEED ${ }^{\circledR}$ for Existing Buildings: Operations \& Maintenance}




\section{Attachment F}

\section{Checklist for LEED ${ }^{\circledR}$ for Existing Buildings: Operations \& Maintenance}

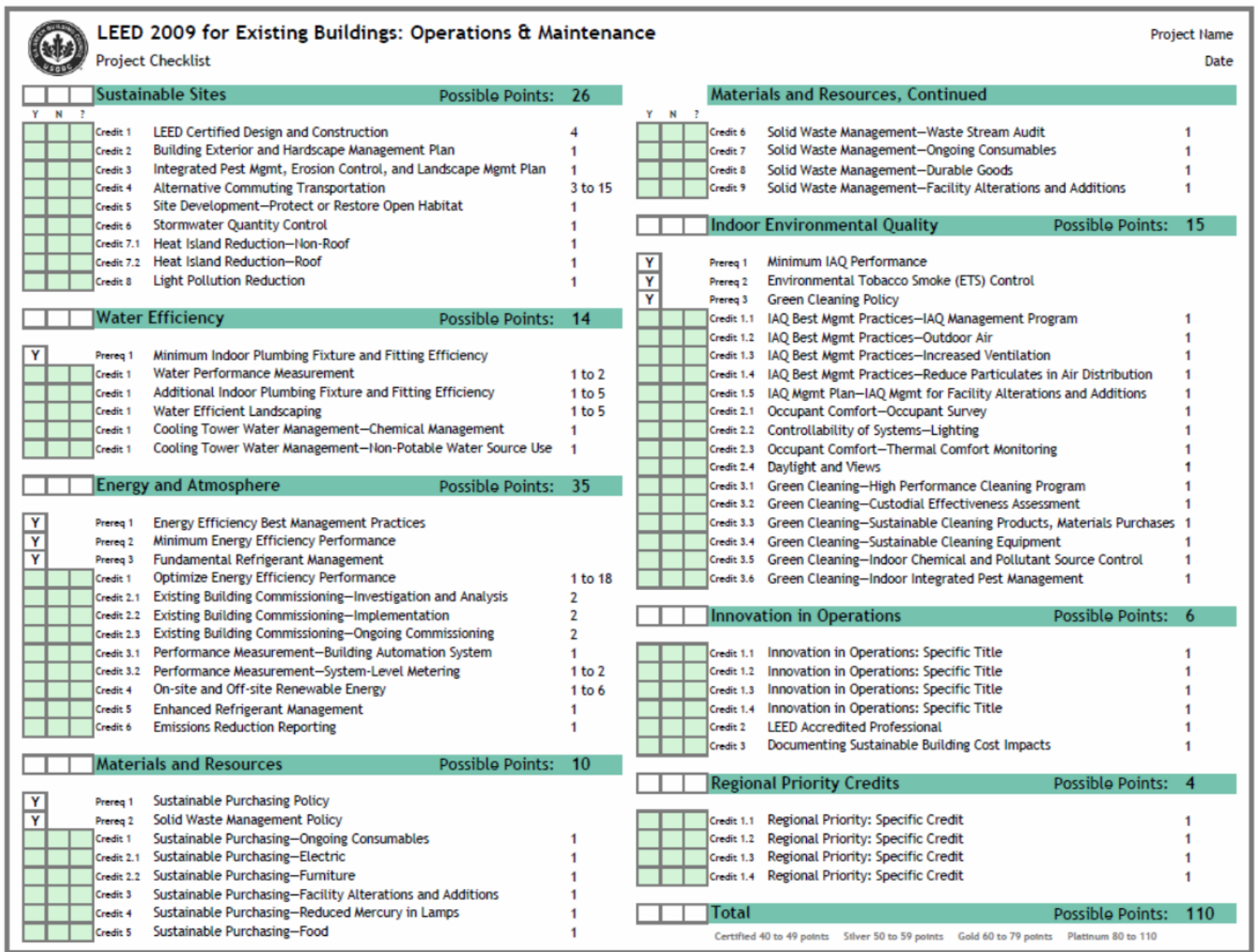




\section{Attachment G}

\section{Checklist for LEED ${ }^{\circledR}$ for Core and Shell}




\section{Attachment G}

\section{Checklist for LEED ${ }^{\circledR}$ for Core and Shell}

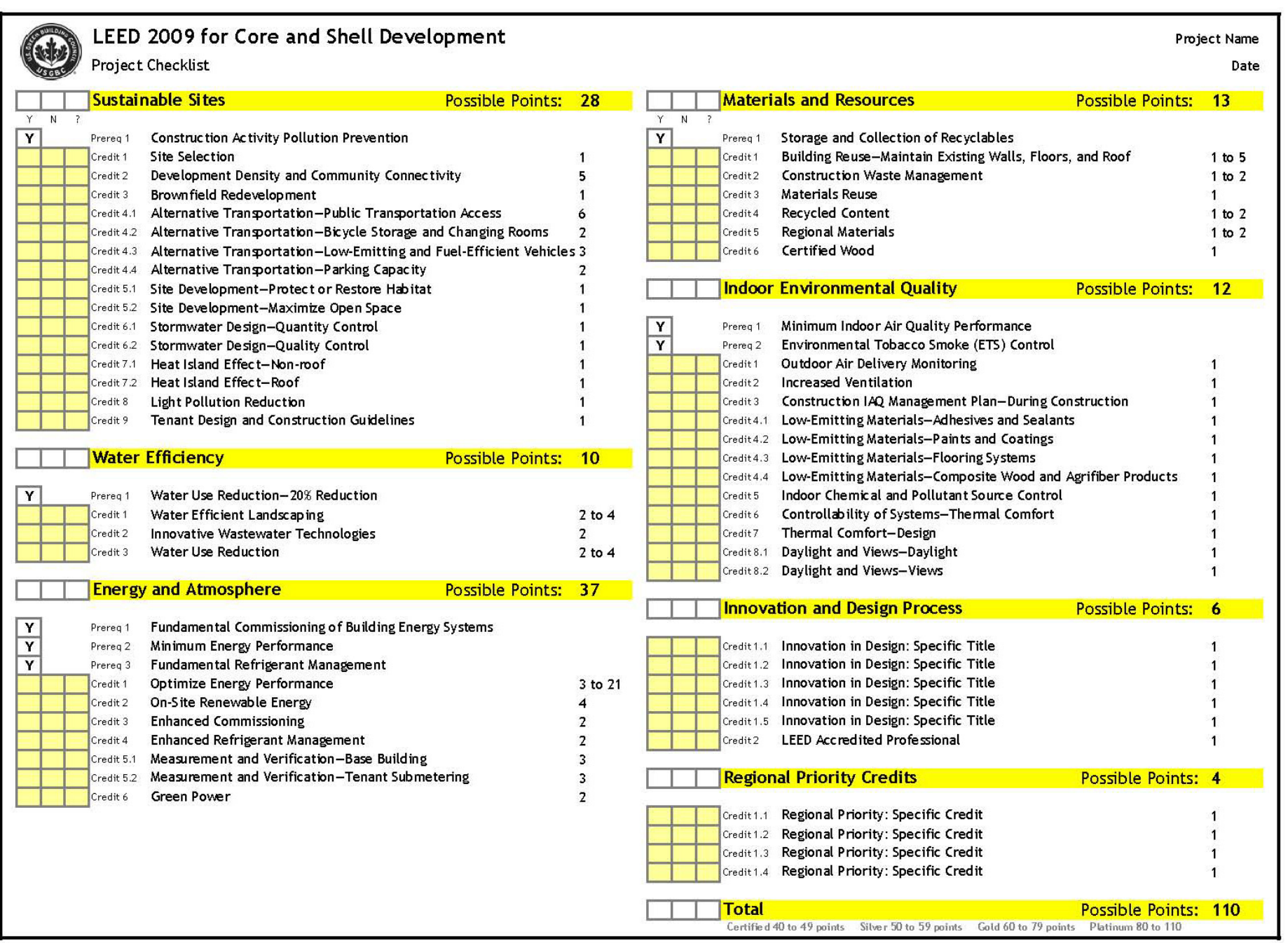




\section{Attachment $\mathrm{H}$}

\section{Checklist for LEED ${ }^{\circledR}$ for Commercial Interiors}




\section{Attachment H}

\section{Checklist for LEED ${ }^{\circledR}$ for Commercial Interiors}

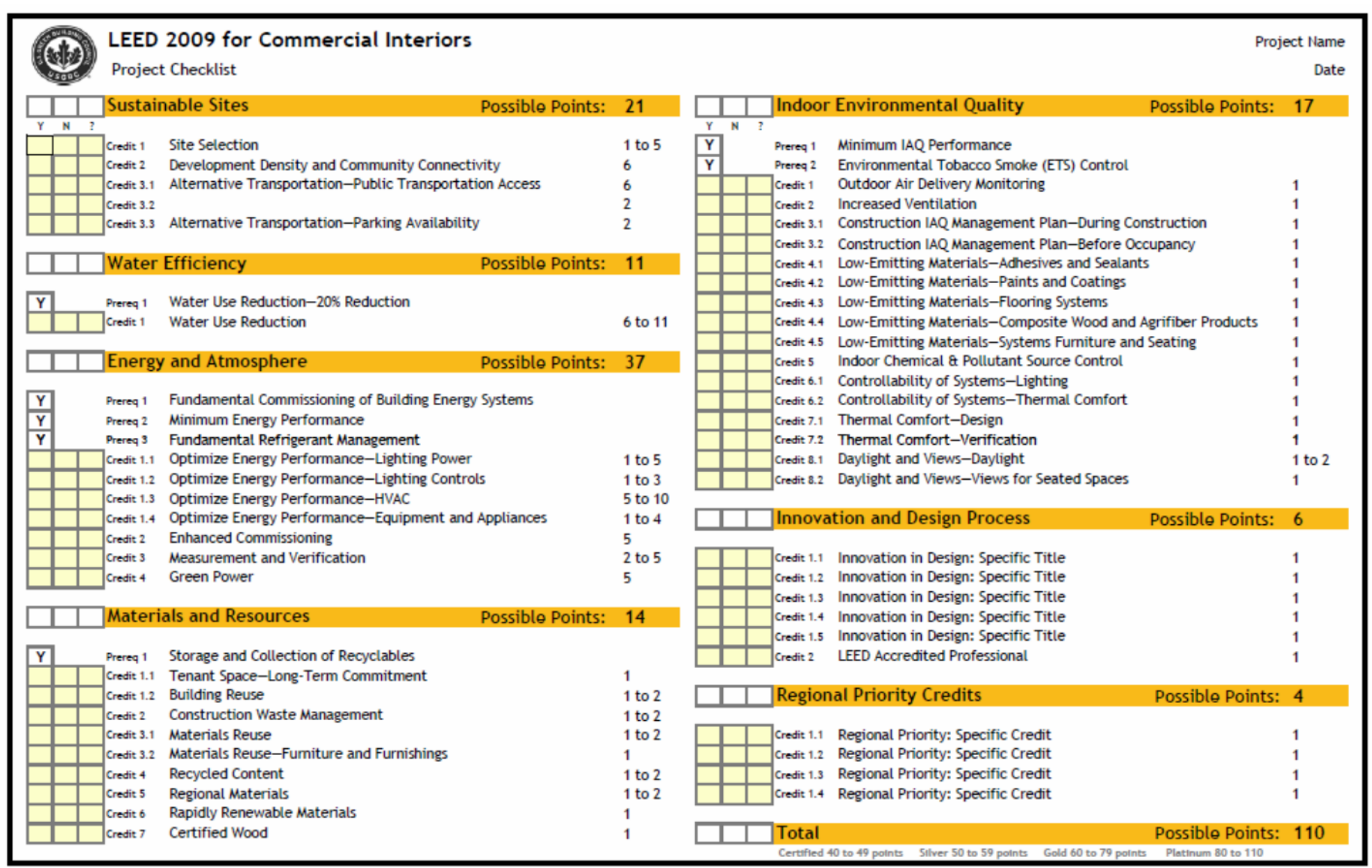

